Baş, B. , Turhan, O. ve Karaca, F. (2017). Türkçe öğretiminde etkinlik stratejisi geliştirmeye yönelik bir durum tespiti: 5. Sınıf Türkçe çalışma ve öğretmen kılavuz kitabı örneği. Ana Dili Eğitimi Dergisi, 5(4), 717-746.

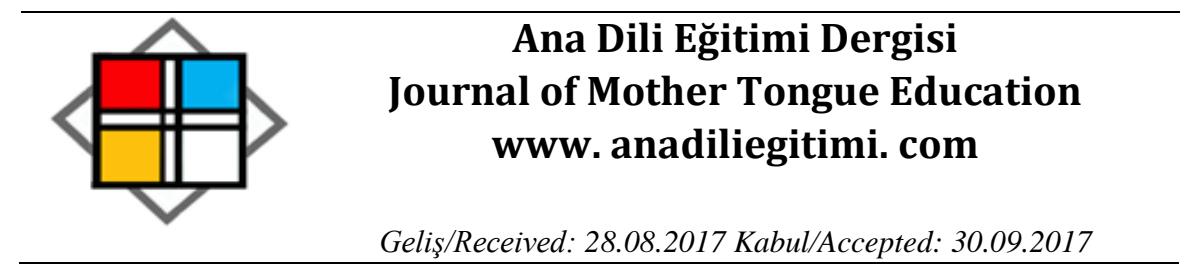

\title{
Türkçe Öğretiminde Etkinlik Stratejisi Geliştirmeye Yönelik Bir Durum Tespiti: 5. Sınıf Türkçe Çalışma ve Öğretmen Kılavuz Kitabı Örneği*
}

\author{
Bayram BAŞ $S^{* *}$ \\ Osman TURHAN*** \\ Fatma KARACA ${ }^{* * * *}$
}

Öz

Etkinlik yaklaşımı ve bu doğrultuda etkinlik stratejisi geliştirme süreci, yapılandırmacı yaklaşımın temel boyutlarındandır. Ders kitaplarının yanında çalışma kitapları için hazırlanan ve öğretmen kılavuz kitaplarında yönergeler biçiminde sunulan etkinliklerin nasıl bir stratejiyle hazırlandı̆̆ı, etkinliklerde hangi becerilere yer verildiği ve öğretmenlere bu yönde nasıl bir görevin yüklendiğ cevaplanması gereken önemli sorulardır. Bu çalışma 2015 yılında yayımlanan Türkçe Dersi (1-8. Sınıflar) Öğretim Programı doğrultusunda 2016-2017 öğretim yılında MEB tarafından 5. sınıflar için hazırlanmış Türkçe çalışma kitabında bulunan etkinliklerin ve aynı sınıfın öğretmen kılavuz kitabında yer alan etkinlik yönergelerinin, temel beceriler, zihinsel beceriler ve öğretmen rolü boyutlarıyla değerlendirilmesi amacıyla yapılmıştır. Nitel araştırma yöntemlerinden iç içe geçmiş tek durum deseninin kullanıldığı bu çalışmanın araştırma nesnesini Türkçe 5. Sınıf Çalışma Kitabı ve Öğretmen Kılavuz Kitabı oluşturmaktadır. Çalışma, bu kitapların 1. temasında yer alan etkinlikler ve etkinlik yönergeleriyle sınırlandırılmıştır. Veri toplama aracı olarak 8 basamaktan (Türkçeyi doğru, güzel ve etkili kullanma, eleştirel ve yaratıcı düşünme, iletişim, problem çözme, araştırma, bilgi teknolojilerini kullanma, girişimcilik, karar verme) meydana gelen temel beceriler, 9 basamaktan (sıralama, sınıflama, sorgulama, ilişki kurma, eleştirme, tahmin etme, analiz, sentez, değerlendirme) meydana gelen zihinsel beceriler ve araştırmanın inceleme nesnesinde doküman incelemesiyle elde edilen veriden hareketle oluşturulan 9 basamaktan (dikkat, ön bilgileri harekete geçirme, etkinliğe yönlendirme, plan yapma, bilgiyi bulmaya yönlendirme, bilgiyi sunma, pekiştirme yapma, iletişim, ölçme ve değerlendirme) meydana gelen öğretmen rolü kategorileri doğrultusunda oluşturulan ölçüt listesi kullanılmıştır. Veri betimsel analiz ve içerik analiziyle değerlendirilip 5. sınıf düzeyinde etkinlik geliştirme stratejilerine yönelik tespitlerde bulunulmuştur. Çalışmada etkinliklerin yapılandırmacı yaklaşım doğrultusunda hazırlandığı, temel ve zihinsel becerilerin nitel ve nicel açıdan farklı oransal yeterlilikler gösterdiği ve öğretmene rehberlik rolü tanımlandığı sonucuna ulaşılmıştır.

Anahtar Kelimeler: etkinlik, etkinlik geliştirme stratejileri, temel beceriler, zihinsel beceriler, öğretmen rolü

\footnotetext{
* Bu çalışma 3. Uluslararası Dil Eğitimi ve Öğretimi Sempozyumu'nda (20-23 Nisan 2017, Roma) “Ortaokul 5. Sınıf Türkçe Çalışma Kitabındaki Etkinlik Stratejileri Üzerine Bir Değerlendirme" adıyla sunulan sözlü bildirinin genişletilmiş hâlidir.

** Doç. Dr., Yıldız Teknik Üniversitesi, Türkçe ve Sosyal Bilimler Eğitimi Bölümü, bayrambas@gmail. com

*** Arş. Gör., Yıldız Teknik Üniversitesi, Türkçe ve Sosyal Bilimler Eğitimi Bölümü, osmtrhn@gmail. com

**** Uzm., Yıldız Teknik Üniversitesi, Uluslararası Ilişkiler Koordinatörlüğü, karacafatma@ymail. com
} 


\title{
An Assessment of Activity Development Strategy in Teaching Turkish: The Case of $5^{\text {th }}$ Grade Turkish Workbook and Teacher's Book
}

\begin{abstract}
Activity approach and strategies for developing an activity in line with it constitute one of the main dimensions of the constructivist approach. In the activities which are presented in the form of instructions as accompaniments to text books and teacher's books, the strategy used in their preparation, the skills that were made use of in them, and the responsibility assigned to teachers regarding their use are issues that need to be considered. This study was conducted to evaluate activities in the $5^{\text {th }}$ grade Turkish Workbook prepared by the Ministry of National Education in the 2016-2017 academic year in accordance with the Turkish curriculum (grades 1-8) published in 2015 and instructions for activities in the Teacher's book of the same grade in terms of basic skills, cognitive skills, and teacher roles. In this study which used embedded single case study research design, the objects of study were the $5^{\text {th }}$ grade Turkish Workbook and Teacher's Book. The study was limited to the activities and activity instructions in Unit 1 . As the data collection tool, a list of criteria prepared according to the three criteria which are basic skills which consisted of 8 categories (using Turkish accurately and effectively, critical and creative thinking skills, communication, problem solving, research, using information technologies, entrepreneurship, decision making); cognitive skills which consisted of 9 categories (sequencing, classifying, questioning, associating, criticizing, guessing, analyzing, synthesizing, evaluating); and teacher roles which consisted of 9 categories (attention, activating prior knowledge, guiding toward activity, planning, guiding for finding information, presenting information, reinforcing, communicating, testing and assessment) were used. The data were analyzed using descriptive and content analysis, and strategies for activity development at $5^{\text {th }}$ grade level were identified. The findings of this study show that activities were built around the constructivist approach, that basic and cognitive skills were manifested at different rates, and that teachers' role was identified as that of a guide.
\end{abstract}

Keywords: activity, strategies for developing an activity, basic skills, cognitive skills, teacher role

\section{Giriş}

Yapılandırmacı yaklaşım, öğrenci merkezli ve öğrencinin bilgiyi inşa ettiği bir sürece işaret etmektedir. Öğrenci; hazırlık, uygulama, değerlendirme gibi aşamalardan oluşan öğrenme sürecinde aktif bir rol oynayarak çeşitli zihinsel ve sosyal becerilerini kullanmaktadır. Bu becerilerin kullanımı ve gelişimi, azdan çoğa ya da zayıftan kuvvetliye doğru hiyerarşik bir düzen izlemez. Sarmal bir düzende iç içe geçmiş haldedir. Öğretmen rolü, öğrenci rolü, öğrenme ortamının durumu, ders kitabının niteliği ve öğrenme etkinlikleri bu sarmal düzeni etkileyen değişkenlerdir. Yapılandırmacı yaklaşım çerçevesinde bu değişkenlerin taşıması gereken bazı özellikler bulunmaktadır.

\section{Yapılandırmacı Yaklaşımda Öğretmen, Öğrenci, Ders Kitabı ve Öğrenme Ortamı}

Brooks ve Brooks (1999)'a göre yapılandırmacı bir anlayışa sahip olan öğretmen, öğrencinin özerk olmasını ve inisiyatif almasını teşvik eder. Etkileşim oluşturacak kaynak ve fiziksel malzemeleri kullanır. Öğrenciler için görevleri oluştururken "sınıflandırmak", "analiz etmek", "ön görmek" ve "yaratmak" gibi bilişsel becerileri dikkate alır. Öğretim stratejilerini ve içeriğini değiştirmede öğrencilerin isteklerini göz önünde bulundurur. Öğrencilerin hem kendisiyle hem de birbirleriyle diyaloğa girmesine ortam hazırlar. Öğrencilere açık uçlu sorular sorarak ve onların birbirlerine sorular 
Türkçe Öğretiminde Etkinlik Stratejisi Geliştirmeye Yönelik Bir Durum Tespiti: 5. Sınıf Türkçe Çalışma ve Öğretmen Kılavuz Kitabı Örneği

sormasını sağlayarak öğrencileri sorgulamaya teşvik eder. Soru sorduktan sonra öğrenciye zaman verir. Öğrenci cevaplarını ayrıntılı bir şekilde inceler. Öğrencilerin ilişki ve metafor kurmasına izin verir. Öğrencilere ilk hipotezleriyle çelişen, sonrasında tartışmaya teşvik eden deneyimler sunar.

Yapılandırmacı yaklaşımda öğretmenin görevi; öğrenme ortamını düzenlemek ve öğrencilere rehberlik yaparak onların bireysel farklılarını dikkate almak, çalışma grupları oluşturmak ve öğrencileri kendi öğrenme ortamlarında sorumluluk sahibi kılmaktır (Erdoğan, 2007; Demirel, 2008; Yaşar, 1993'ten akt.: Yaşar, 1998; Günay 2015).

Perkins (1999), yapılandırmacı yaklaşımda öğrenciye atfedilen rolü Phillips (1995)'in görüşlerine dayanarak aktif öğrenci, sosyal öğrenci ve yaratıcı öğrenci olarak belirlemiştir. Aktif öğrenci, sadece dinleme, okuma ve belirlenmiş alıştırmaları yapmak yerine; tartışır, münazara yapar, hipotez kurar, araştııı, bakış açısı geliştirir. Sosyal öğrenci bilgi ve kavramayı ayrı ayrı değil diyalog içinde birlikte yapılandırır. Yaratıcı öğrenci ise bilgi ve kavramayı şekillendirir. Yine Perkins (1992)'e göre öğrenciler etkinlik yönergelerini takip etmez, yönergeleri kontrol eder. Bu sayede öğrencinin özerklik becerisi artar (Akt. Chen, 2003: 21). Öğrenciler özerklik sayesinde derse aktif şekilde katılır. Böylece bilgiyi alarak değil soru sorarak, araştırarak ve problem çözerek öğrenmeyi gerçekleştirirler (Çiftçi, Sünbül ve Köksal, 2013: 282). Bu sebeple değerlendirme sürecinde öğrencilerin anlayış şekillerini ortaya koyabileceği problem çözme ve günlük hayatla bağlantı kurma gibi etkinliklerin bulunması gerekmektedir (Ocak ve Tavlı, 2010). Ayrıca grup tartışmaları ve iş birliği ile öğrencilerin nitelikli bir etkileşim içinde olması sayesinde kalıcı, yaşamla ilişkili ve anlamlı öğrenme sağlanır. Bu öğrenme durumları, sadece bilişsel düzeyde olmayıp aynı zamanda farklı görüşlere saygılı olma, kendine güvenme ve dinlemeyi öğrenme gibi duyuşsal öğrenme niteliği de gösterir (Koç, 2010: 63).

Davranışçı kuram doğrultusunda hazırlanan ders kitapları araç değil amaç özelliği göstermektedir. Bu ders kitaplarında, öğrenci bilgi ve beceri açısından metnin sınırlarını aşarken güçlük çekmektedir. Bu ders kitaplarının alıştırmaları, bilgiyi sunan ana kaynak ya da bilginin tekrarı ve pekiştireci özelliklerini taşımaktadır. Yapılandırmacı yaklaşımdaysa ders kitapları ve kitapların içerikleri bir araçtır. Bu ders kitaplarıyla ilişkili etkinlikler düşünme süreçlerini tetikleyen; çeşitli öğrenme alanlarını birleştiren, sorgulatan, yorumlatan; sosyal becerileri geliştiren özellikler göstermektedir.

Yapılandırmacı amaçla hazırlanmış ders kitapları ortak bir yapı oluşturacak etkinlikler ve açık uçlu sorular içermeli (Özatalay, 2007); otantik metinlerden oluşmalı, ampirik öğrenme etkinliklerine yer vermeli, öğrencileri sınıf dışı bilgi teknolojilerini kullanmaya teşvik etmeli ve işbirlikçi öğrenme özelliği göstermelidir (Tarnopolsky, 2017: 58-59). 
Yapılandırmacı yaklaşımda öğrenme ortamı; öğretmenin, öğrencinin, öğrenme sürecinde kullanılacak materyallerin, yöntem ve tekniklerin birbiriyle kurduğu bağlantının niteliğiyle anlam kazanmaktadır. Yapılandırmacı yaklaşıma uygun olan bir derste öğretim, öğrencilerin birbirleriyle etkileşim içinde olması, öğrencilerin önceden edinmiş oldukları bilgilerin ve tecrübelerin öğrenmeyi ve yeni bilgileri yapılandırmayı kolaylaştıran bir kaynak olarak görülmesi, öğrencinin var olan bilgisiyle çözülecek sorun ve toplumsal çevre arasında bağlam kurması üzerine şekillenmektedir (Ocak ve Tavlı, 2010; Özerbaş, 2007). Fakat derslerin işlenişinde içerik sadece genel hatlarıyla bellidir, içeriğin sınırları kesin değildir. Öğrencilerin kullanması için bir miktar mevcut içerik bulunmakla birlikte öğrenciler, çalıştıkları konu üzerindeki bakış açılarını derinleştirecek alternatif bilgi kaynaklarını aramaları için teşvik edilir (Gönen ve Andaçi, 2009). Yapılandırıcı öğrenme ortamında sunulan içerik/konular tüm öğrencilerin fark edebileceği, motive olabileceği şekilde öğrencilerle alakalı olmalıdır. Bilgi, kavramsal olarak kümelenmiş problem ve durumlar çevresinde birincil kavramların etrafında yapılandırılarak sunulmalıdır. Öğrenme sürecindeki öğrencilerin görüşleri ve iletişimi kurma süreci dikkate alınmalıdır. Öğrencinin öğrendikleri, öğrenme sürecinden ayrı bir şekilde değerlendirilmemeli, değerlendirmeye yönelik olumlu dönütlerde bulunulmalıdır. Ders öğretim programının öğrencilere yönelik bilişsel, sosyal ve duyuşsal beklentisiyle öğrencilerin etkinlikler aracılığıyla elde edeceği kazanımlar arasında bağlantı olmalıdır. Öğrencilerin bu kazanımlara erişme sürecinde öğretim ortamlarında kullanılabilecek ve yapılandırmacı yaklaşımın doğasına uygun bazı yöntem ve teknikler bulunmaktadır (Brooks ve Brooks, 1999). Bunlardan bazıları; hedef konu ile ilgili daha derin bir bakış açısının ortaya konduğu ya da konunun diğer yönlerinin görülebildiği sınıf içi tartışmalar; bir beceri ya da kavramı öğrenen öğrencinin onu öğrenmeyene öğretmesiyle oluşan akran öğretimi; öğrencilerin diğerleriyle işbirliği içerisinde çalışabilme yeteneğini geliştiren işbirlikçi öğrenme (Schunk, 2009); bireylerin öğrenme sürecine etkin olarak katıldıkları ve çalışmaları yönlendirdikleri anlamlı ve kalıcı öğrenmeyi sağlayan probleme dayalı öğrenme (Yaşar, 1998: 70); öğrenenlerin kendilerine verilen bilgileri kullanıp kendi anlayışlarını yapılandırdığı buluşa dayalı öğrenme; öğrenenlerin kendilerine sorulan sorular üzerine hipotez kurup bilgi topladığı ve sonuca ulaşmaya çalıştığı sorgulama yöntemi; üst düzey düşünmeyi ve iletişimi sağlayan gözlem (Yurdakul, 2005: 54-55) şeklinde sıralanabilir.

\section{Etkinlik Yaklaşımı ve Yapılandırmacı Yaklaşımda Etkinlik}

Etkinlik yaklaşımı, yapılandırmacı yaklaşımla yakından ilişkili olup öğretim sürecinde kullanılan önemli araçlar olan etkinliklerde bulunması gereken önemli özellikler üzerine şekillenmiştir. Bu yaklaşım sosyallik, birey, sorumluluk, süreç, zihinsel yapılandırma, tecrübe gibi kavramlardan oluşmaktadır. Bu yaklaşımda öğrenen öğrenme sürecinde aktiftir. Sosyal ve zihinsel değişkenlerle dil becerilerini geliştirmektedir. Problem özelliği gösteren durumlara çözümler ve yorumlar 
Türkçe Öğretiminde Etkinlik Stratejisi Geliştirmeye Yönelik Bir Durum Tespiti: 5. Sınıf Türkçe Çalışma ve Öğretmen Kılavuz Kitabı Örneği

getirebilmektedir. Güneş (2017: 55) etkinlik yaklaşımının tanımını ve önemini "öğrencilerin aktif öğrenmelerini sağlamak için düzeylerine uygun çeşitli görev ve etkinlikler verilmekte, bunların uygulanması istenmektedir. Bu yaklaşıma göre öğrencileri güdüleme, öğrenme sürecini kolaylaştırma, öğrenciler arasında iletişim ve etkileşimi artırma açısından etkinlikler çok önemli olmaktadır." şeklinde ifade etmiştir.

Etkinlik yaklaşımı görev tabanlı bir özellik göstermektedir. "Görev" kavramı ile öğrencilerin gerçek bir sonuç elde etmek için dil kullandıkları hedef odaklı bir faaliyet kastedilmektedir. Bir başka deyişle, öğrenciler bir problemi çözmek, bulmaca yapmak, oyun oynamak veya deneyimleri paylaşmak ve karşılaştırmak için sahip oldukları hedef dilin kaynaklarını kullanırlar (Willis, 1996). "Bu yaklaşımda öğrenme etkinlikleri, öğrencilerin koşullarına ve eğitim ortamının sınırlılıklarına dikkat edilerek oluşturulur. Her bir öğrenme etkinliğinin hangi zihinsel ya da temel beceriyi geliştirdiği belli olmalı, etkinliğin içeriği ona göre oluşturulmalıdır. Etkinliklerin tek tip olma zorunluluğu yoktur. Öğrenci bireysel olarak ele alınabilir. Fakat bu öğrencinin bir grup içinde aktif bir rol oynaması göz ardı edilmemelidir. Öğrenci, kitap okuyarak ve öğretmeni dinleyerek bilgi ve beceri edinmek yerine öğrenme ortamındaki çevresiyle tartışarak ve sorgulayarak aktif bir katılım sergiler" (Güneş, 2011). Özmantar ve Bingölbali (2009) bu tip etkinliklerin oluşturulmasında dikkat edilmesi gereken prensipleri; etkinliğin amacı, etkinlik uygulamasında sınıf yönetimi, etkinliğin birden fazla başlangıç noktasının olması, etkinlikte kullanılacak materyaller/araçlar, öğretmen ve öğrenci rolleri, öğrencilerin ön bilgileri, öğrenci zorluk ve yanılgıları ve ölçme ve değerlendirme şeklinde açıklamıştır.

Etkinliklerle kuvvetli bir bağı olan öğrenciye, öğretmene ve öğretim ortamına yüklenen sorumlulukların gerçekleştirilebilmesi için etkinliğin üretildiği zihinlerin farklı değişkenler açısından nitelikli olması gerekmektedir. Bukova-Güzel ve Alkan (2005: 408), bu değişkenlerden bazılarını şu şekilde açıklamaktadır: "Etkinlik üretmek, bir yandan değişik düşünme alışkanlığı, öte yandan da bireysel yaratıcılık gerektiren zor bir iştir. Özellikle günlük yaşamla bağlantılı etkinlik oluşturulabilmek için hem bireysel alan bilgisinin yeterli olması hem de genel kültürün üst düzeyde bulunması kaçınılmazdır. Bu, her şeyden önce çok çalışmayı ve var olan eksiklikleri gidermeyi zorunlu kılmaktadır. Aksi hâlde yüzeysel olarak düşünerek, basit bir örnek çözümünü ya da bir soru sormayı etkinlik sayarak sistemi yozlaştırma yanılgısına düşülebilir".

Etkinlikler birincil ya da ikincil kaynaklardan beslenebilmektedir. Birincil kaynaklar, öğrencilerin doğrudan deneyimleyerek bilgi edindikleri kaynaklardır. İkinci kaynaklar öğretim esnasında sunulmaktadır ve başka kişiler tarafından oluşturulmuştur. Yapılandırmacı yaklaşımda esas olan birincil kaynaklardır. Çünkü öğrenciler kendilerine bilgi aktarılan kişi değildir. Birincil kaynakla sunulan bilgiler, öğrencilerin anlamlandırması, derinlemesine işlemesi ve yorumlaması gereken uyarıcılardır. İkincil kaynaklar farklı görüşleri yansıtıyorsa, yorumlanabiliyorsa, etkin katılımı 
sağlayabiliyorsa yapılandırmacı etkinliklere uygundur (Deryakulu, 2000). Yani öğrenim sürecinde kullanılacak etkinlikler; gerçekçi materyallerle oluşturulmalı; etkin öğrenmeyi desteklemeli; bilişsel üst düzey becerilerin kullanılmasına olanak sağlayan işbirlikçi çalışmaya ve paylaşıma uygun olmalı; probleme dayalı olmalı ve sorgulamaya, araştırmaya, tartışmaya yer vermelidir (Çubukçu, 2010). Özellikle işbirlikçi öğrenme tarzına uygun etkinlikler öğrencinin kendini ifade etme, isteklerini ifade etme, duygularını tanıma ve ifade etme, öfke yönetimi, duygu yönetimi, empati, etkili dinleme, önyargılarla başa çıkma, eleştiriyle başa çıkma, farklılıkları yönetme, hoşgörü, sorun çözme, karar alma gibi yaşam becerilerini öğrenmesi açısından önem arz etmektedir (Türnüklü ve Bekmezci, 2010: 31). Ayrıca farklı yönleriyle açıklanan tüm bu etkinlikler; benzetim ve rol çalışması, durum analizi, örnek olay incelemesi gibi başka şekillerde de oluşturulabilirler (Çubukçu, 2010).

Öğretim sürecine yönelik oluşturulan etkinlikler aracılığıyla öğrencilerin temel becerilerinin ve zihinsel becerilerinin gelişmesi beklenmektedir. Temel beceriler ve zihinsel beceriler, dil öğretimi programlarında yer yer özel olarak belirtilmiş, bazen de farklı bölümler içinde değerlendirilmiştir. Bu sebeple Türkçe dersi öğretim programlarındaki temel becerilere ve zihinsel becerilere göz atmak faydalı olacaktır.

\section{Türkçe Dersi Öğretim Programında Temel Beceriler ve Zihinsel Beceriler}

Millî Eğitim Bakanlığının 2015 yılında yayımladığı Türkçe Dersi (1-8. Sınıflar) Öğretim Programı yapılandırmacı yaklaşımdaki öğretmen ve öğrenci rollerine, ders kitabı niteliklerine ve öğrenme ortamına dayanılarak hazırlanmıştır. Bu programda temel beceriler ve zihinsel becerilere özel olarak değinilmiştir. Yine son olarak MEB (2017)'in yayımladığı Türkçe Dersi Öğretim Programı (illkokul ve Ortaokul 1, 2, 3, 4, 5, 6, 7 ve 8. Sınıflar)'nın farklı bölümlerinde temel becerilere ve zihinsel becerilere değinilmiştir.

Türkçe Dersi (1-8. Sınıflar) Öğretim Programı (MEB, 2015)'nda tüm zihinsel becerilerin çıkış noktası ve bu becerilerin kendi içinde gelişiminin ve diğer becerilerle etkileşiminin temel unsuru olan düşünme; "öğrencilerin edindiği bilgi ve becerileri kullanması, bir konu hakkında yorum yapması ve bir konuyu değişik biçimlerde gördüğünde fark etmesi" (Karaman, 2005: 81) olarak değerlendirilen anlama; basit ya da karmaşık değişkenler açısından bağlantılı bilgilerin, olayların, durumların öncelik ve sonralık kıstasına göre belirli bir düzene konulmasını sağlayan sıralama; basit ya da karmaşık değişkenler açısından ilgili bilgilerin, olayların, durumların belli bir düzen içinde kategorize edilmesini ya da kategori içinden çıkartılmasını sağlayan sınıflama; "bilgi ve kanıtların incelenip doğruluğunun ölçülmesine, neden ve sonuçların belirlenmesine, çıkarımların ve tartışmaların yapılmasına" (MEB, 2009: 153) olanak sağlayan sorgulama; iki ya da daha fazla olgu, olay, bilgi ya da durum arasında bağ kurma olarak tanımlanabilecek ilişki kurma; "bir konu hakkında karar vermek için dayanak ve kanıt elde etmeye, tutarlılığa, açıklığa ve doğruluğa dayalı" (Özdemir, 2005: 2-3) olan eleştirme; "bir olayın 
Türkçe Öğretiminde Etkinlik Stratejisi Geliştirmeye Yönelik Bir Durum Tespiti: 5. Sınıf Türkçe Çalışma ve Öğretmen Kılavuz Kitabı Örneği

geleceğine ya da sonucuna yönelik eldeki verile ve geçmişte edinilen deneyimlerle yapılan kestirme işi” (Anagün ve Yaşar, 2008: 846) olan tahmin etme; bir bütünü oluşturan parçaların, ilişkilerin ve ilkelerin ayırt edilmesini sağlayan analiz; ögeler arasında belirli ilişki ve kurala göre "yenilik, özgünlük, yaratıcılık gibi özelliklere sahip" (Koray, Altunçekiç ve Yaman, 2005: 34) olan bir bütün (yeni bir ürün) oluşturma işinin yapıldığı sentez; "nitelik, etkililik, yeterlilik veya uygunluk gibi belirlenmiş ölçütlere başvurarak olumsuz ya da olumlu karar verme"(Kala, 2015: 68) becerisi olan değerlendirme gibi zihinsel becerilere yer verilmiştir.

Türkçe Dersi (1-8. Sınıflar) Öğretim Programı (MEB, 2015)'nda Türkçenin kurallarına uygun, estetik ve etkileşimi sağlayacak şekilde kullanılmasına işaret eden Türkçeyi doğru, güzel ve etkili kullanma; "gerçek ve iddialar arasındaki farklılığı gösterme, bilgi kaynağının güvenilirliğini test etme, önyargı ve bilişsel hataları fark etme vb." (Yahşi Cevher, 2006: 26) hususlara temas eden eleştirel düşünme; öğrencilerin yeniyi bulabilmelerine fırsat oluşturan yaratıcı düşünme; yaşamın doğrudan sosyal yönünü oluşturan iletişim kurma; "sorunu tespit etme, alternatif çözüm üretme, çözümü planlama, uygulama ve değerlendirme" (Akgündüz vd., 2015) gibi sistematik süreçlerden oluşan problem çözme; "'Problemi fark etme, problemi çözmek amacıyla araştırmanın planlanması, sonuçları tahmin etme, sorunları kestirme ve test etme, fikirleri geliştirme" (MEB, 2005: 11) gibi kestirme ve yordama özellikleri taşıyan araştırma; "objektif ve alternatif yollar deneyerek öğrencinin zekice seçimler yapmasını sağlayan" (Kan, 2006: 66) karar verme; teknolojik gelişimler doğrultusunda öğrencinin bilgiyi işlemesini sağlayan bilgi teknolojilerini kullanma ve "ikna yeteneği, yaratıcılık, yüksek farkındalık gibi sosyal ve bireysel yönleriyle ve intiyaçları görme, risk alma, fırsatları yakalama ve hayata geçirme gibi ekonomik açıdan öğrenciye olanak sağlayan" (Bozkurt ve Erdurur, 2013; Kurudayıoğlu ve Çetin, 2015; Karadeniz, 2010) girişimcilik gibi temel becerilere yer verilmiştir.

Bu çalışmada yapılandırmacı yaklaşım zemininde Türkçe Dersi (1-8. Sınıflar) Öğretim Programı (MEB, 2015) temel yaklaşımına dayanarak Millî Eğitim Bakanlığı tarafından 2016-2017 öğretim yılı için hazırlanan Ortaokul Öğretmen Kılavuz Kitabı 5. Sınıf'taki etkinlik yönergelerinin ve Ortaokul Çalışma Kitabı Türkçe 5. Sınıf'taki etkinliklerin etkinlik geliştirme stratejileri doğrultusunda incelenmesi amaçlanmıştır. Bu amaç doğrultusunda aşă̆ıdaki sorulara yanıt aranmıştır:

1. Öğretmen kılavuz kitabındaki yönergelerde ve çalışma kitabındaki etkinliklerde temel beceriler nasıl bir dağııım göstermektedir?

2. Öğretmen kılavuz kitabındaki yönergelerde ve çalışma kitabındaki etkinliklerde zihinsel beceriler nasıl bir dağılım göstermektedir?

3. Öğretmen kılavuz kitabındaki yönergelerde ve çalışma kitabındaki etkinliklerde öğretmene nasıl bir rol biçilmiştir? 


\section{Yöntem}

Araştırmada, durum çalışması desenlerinden "iç içe geçmiş tek durum" deseni kullanılmıştır. Bu desende bir durum içinde birden fazla alt tabaka ya da birim bulunmaktadır. (Yıldırım ve Şimşek, 2013: 327) Araştırmada Ortaokul Çalışma Kitabı Türkçe 5. Sınıf ve Ortaokul Öğretmen Kılavuz Kitabı 5. Sınıf tek durum olarak ele alınmıştır. Alt tabakaları ise "zihinsel beceriler", "temel beceriler", “öğretmen rolü" oluşturmaktadır.

\section{Veri Toplama Aracı}

Bu araştırmada Millî Eğitim Bakanlığı tarafından 2016-2017 öğretim yılı için hazırlanan Ortaokul Çalışma Kitabı Türkçe 5. Sınıf ve Ortaokul Öğretmen Kılavuz Kitabı Türkçe 5. Sınıf'ta yer alan 1. Tema (Vatandaş Bilinci)'daki 7 Metin (Padişahın Kulakçıbaşısı, Ödevsiz Gezegen, Vergi Bilir, Memleket İsterim, Dük Oldu Hödük, Gece Karası Adında Bir Karga, Tüketicinin Bilinç Gücü)'e yönelik sözlü iletişim (dinleme, konuşma), okuma ve yazma öğrenme alanlarındaki 39 etkinlik doküman incelemesine tabi tutulmuştur.

Türkçe Dersi (1-8. Sınıflar) Öğretim Programı'nda bulunan zihinsel becerilerden düşünme basamağı ve anlama basamağı etkinlik oluşturma stratejilerindeki yapı ve işlev sebebiyle tüm etkinliklerde var kabul edilmiştir. Bunlar dışında kalan zihinsel beceri (sıralama, sınıflama, sorgulama, ilişki kurma, eleştirme, tahmin etme, analiz, sentez, değerlendirme) ve temel beceri (Türkçeyi doğru güzel ve etkili kullanma, eleştirel ve yaratıcı düşünme, iletişim, problem çözme, araştırma, bilgi teknolojilerini kullanma, girişimcilik, karar verme) basamaklarında ise her bir etkinlik için kılavuz kitapta yer alan yönergeler ayrıntılı bir şekilde incelenmiş ve etkinliklerde yer alıp almama durumuna göre Var (1) ya da Yok (0) şeklinde bir ölçüt listesi geliştirilmiştir. Ardından her bir beceri için toplam bir sayı elde edilmiş ve bunların tema içindeki yüzdeliği belirtilmiştir. Zihinsel becerilerden eleştirme, temel becerilerden eleştirel ve yaratıcı düşünme becerisindeki eleştirel düşünme; yapısı itibariyle etkinliklerde hem sorgulama hem de değerlendirme basamağı ile girişik olduğu için eleştirme/eleştirel düşünme basamağına yönelik ayrı bir kategori oluşturulmamış, bu beceriler değerlendirme ve sorgulama basamaklarının içinde ele alınmıştır.

Ortaokul Öğretmen Kılavuz Kitabı Türkçe 5. Sınıf'a yapılan betimsel analiz ve içerik analizi sonucu önceden belirlenen ölçüt listesine, veri analizi aşamasında 'öğretmen rolü' üst başlığı altında "dikkat, ön bilgileri harekete geçirme, etkinliğe yönlendirme, plan yapma, bilgiyi bulmaya yönlendirme, bilgiyi sunma, pekiştirme yapma, iletişim, ölçme ve değerlendirme" alt başlıklarından oluşan dokuz kategori daha eklenmiştir. Temel becerilerden olan iletişim basamağı, öğretmen aracılığıyla başlatıldığı ve yönlendirildiği için bu üst başlık altında yorumlanması uygun görülmüştür. 
Türkçe Öğretiminde Etkinlik Stratejisi Geliştirmeye Yönelik Bir Durum Tespiti: 5. Sınıf Türkçe Çalışma ve Öğretmen Kılavuz Kitabı Örneği

Öğrencilerin rolüne yönelik değerlendirmeler temel beceriler, zihinsel beceriler ve öğretmen rolü kategorilerinin altında bulunduğu için ayrı bir kategorilendirme yapılmamıştır.

\section{Veri Analizi}

Veri toplama aracında yer alan işaretlenmiş veri betimsel analiz ile değerlendirilmiş ve buna yönelik yorumlar yapılmıştır."Betimsel analiz yaklaşımına göre, elde edilen veri daha önceden belirlenen temalara göre özetlenir ve yorumlanır" (Yıldırım ve Şimşek, 2013; 256). Betimsel analize tabi tutulmuş veri, bulgular kısmında iki farklı şekilde sunulmuştur:

1. Kelime öbeği şeklindeki anahtar ifadeler

2. Özetlenmiş ya da kısaltılmış ifadeler

Ayrıca veri betimsel analize tabi tutulduktan sonra içerik analizi ile derinlemesine yorumlanmıştır."Betimsel analizde özetlenen ve yorumlanan veri, içerik analizi ile daha derin bir işleme tabi tutulur ve betimsel bir yaklaşımla fark edilmeyen kavram ve temalar bu analiz sonucu keşfedilebilir" (Yıldırım ve Şimşek, 2013: 259).

Zihinsel becerilerin kendi içindeki ilişkisine ve temel becerilerle bağlantısına, aynı zamanda temel becerilerin kendi içindeki ilişkisine ve zihinsel becerilerle olan bağlantısına, öğretmen rolüne ait geliştirilen ölçüt listesine ve tüm bunların sonucunda öğrencilere atfedilen role içerik analizi sonucunda ulaşılmıştır. Öğrenciye atfedilen rol, ayrı ayrı şekilde hem "temel beceriler" hem "zihinsel beceriler" hem de "öğretmen rolü" kategorisinde bulunduğundan tekrara düşmemek için bulgular bölümünde ayrı bir alt başlık altında incelenmemiştir.

\section{İnandırıcılık ve Aktarılabilirlik}

Bu çalışmada yer alan zihinsel ve temel becerilere ait ölçüt basamakları Türkçe Dersi (1-8. Sınıflar) Öğretim Programı (MEB, 2015)'ndan alınmış, her bir basamak öğretmen kılavuz kitabındaki yönergeler doğrultusunda incelenmiş ve kategorinin özelliklerine göre belirlenmiştir. Etkinliklerde öğretmene ve öğretmen aracılı̆̆ıyla öğrenciye atfedilen özelliklerin kategorilendirilmesinde çalışma kitabı ve öğretmen kılavuz kitabının yanı sıra yapılandırmacı yaklaşımda ortaya konulan öğretmen ve öğrenci figüründen faydalanılmıştır. Araştırmanın güvenirliğini sağlamak amacıyla verinin tespit edilmesinde birden fazla alan uzmanı araştırma yapmış ve her bir araştırmacının tespit ettiği sonuç diğerleri ile karşılaştırılmıştır. Alan araştırmacılarının mutabık kalmadığı noktalarda yeniden değerlendirmeye gidilmiş ve ortak bir sonuca ulaşılmıştır. Bu sebeplerden dolayı çalışma inandırıcı niteliktedir.

Elde edilen veri bilimsel süreçler doğrultusunda işlendiği ve belirli kategorilere ait olduğu için başka araştırmalara referans gösterilebilir niteliktedir. Bu durum araştırmayı aktarılabilir kılmaktadır. 


\section{Bulgular ve Yorum}

Bu bölümde verinin toplanması ve analizi sonucunda, "zihinsel beceriler, temel beceriler, öğretmen rolü" şeklindeki üç kategori hakkında elde edilen bulgular sunulmuş ve yorumlanmıştır.

\section{Zihinsel Becerilere Yönelik Bulgular ve Yorumlar}

Zihinsel becerilere yönelik elde edilen veri aşağıdaki tabloda gösterilmiştir:

Tablo 1. Zihinsel Becerilere Yönelik Sayısal Bulgular

\begin{tabular}{lcc}
\hline Zihinsel Beceriler & Bulunduğu Etkinlik & $\%$ \\
\hline Sıralama & 4 & 10 \\
\hline Sınıflama & 8 & 20 \\
\hline Sorgulama & 23 & 59 \\
\hline ilişki Kurma & 20 & 51 \\
\hline Eleştirme & 19 & 49 \\
\hline Tahmin Etme & 9 & 23 \\
\hline Analiz & 34 & 87 \\
\hline Sentez & 19 & 49 \\
\hline Değerlendirme & 22 & 56 \\
\hline
\end{tabular}

1. temada bulunan 7 metindeki toplam 39 etkinlik içinde; sıralama becerisi 4 (ortalama \%10), sınıflama becerisi 8 (ortalama \%20), sorgulama becerisi 23 (ortalama \%59), ilişki kurma becerisi 20 (ortalama \%51), eleştirme becerisi 19 (ortalama \%49), tahmin etme becerisi 9 (ortalama \%23), analiz becerisi 34 (ortalama \%87), sentez becerisi 19 (ortalama \%49), değerlendirme becerisi 22 (ortalama \%56) etkinlikte kullanılmıştır.

Etkinliklerdeki kullanım sıklığı dağıımına göre "analiz" becerisini; "değerlendirme, sorgulama, eleştirme, sentez ve ilişki kurma" becerileri takip etmektedir. Etkinliklerde en az yer verilen becerilerse "sınıflama, sıralama ve tahmin etme" becerileridir. Zihinsel becerilere yönelik kategoriler ve bulgular aşağıda başlıklar hâlinde sunulmuştur.

\section{Siralama}

Sıralama becerisi kategorisinde çalışma ve öğretmen kılavuz kitabında öğrenciden beklenenler aşağıdaki gibidir:

"Bir ürünün yapımından satışına kadarki aşamaları belirlemek, bir sonucun sebeplerini anlayabilmek için bu sebepleri kendi içinde sıralamak."

Sıralama becerisi nicel açıdan az olduğu için etkinlik süreci içinde bu basamağın yoğunlaştığı bir nokta yoktur. Sıralama basamağı iki farklı şekilde kullanılmıştır. Illk kullanımında öğrencilerden günlük hayatıyla ilişkili bir ürünün yapım ve satış sürecini, deneyimlerinden ve tahminlerinden hareketle yapılandırması istenmektedir. İkinci kullanımında öğrencilerden metin sonucunda oluşan olayın sebeplerini, metni daha iyi anlayabilmek için sıralaması istenmektedir. Illk durumunda öğrenci 
Türkçe Öğretiminde Etkinlik Stratejisi Geliştirmeye Yönelik Bir Durum Tespiti: 5. Sınıf Türkçe Çalışma ve Öğretmen Kılavuz Kitabı Örneği

aktif, bilgiyi oluşturan ve yapılandıran bir roldeyken ikinci kullanımda var olan bilgiyi ayrıştıran pasif bir roldedir.

Sinıflama

Sınıflama becerisi kategorisinde çalışma ve öğretmen kılavuz kitabında öğrenciden beklenenler aşağıdaki gibidir:

"Birçok örneği belirli kavramlar altında sınıflamak, ilişkili kavramları bir kavram altında toplamak, bir kategori altına o kategori ile ilgili örnekler yazmak, düşünceleri giriş-gelişme-sonuç şeklinde yazıya dökerek aktarmak."

Sınıflama becerisinde daha çok kavramlardan faydalanılmıştır. Yani sınıflandırılması istenen şeyler çoğunlukla kelime ve kelime grupları olarak belirlenmiştir. Sınıflandırmalarda bazen üst başlıklar verilip kavramların başlık altına sınıflandırılması istenmiş, bazen de dağınık olan ilişkili kavramların üst başlık altında toplanması istenmiştir. Sınıflandırma çoğunlukla temel düzeyde kalmıştır. Düşüncelerin giriş-gelişme-sonuç bölümleri altında sınıflandırılması gibi birbiriyle çeşitli açılardan ilişkisi olan durumların kategorilendirilmesine oldukça az yer vermiştir. Ayrıca sınıflama kitaptaki etkinliklere hazırlık yapma, metnin kavranmasını pekiştirme ve ortaya yeni bir ürün koyma gibi amaçlarla kullanılmıştır.

Sorgulama

Sorgulama becerisi kategorisinde çalışma ve öğretmen kılavuz kitabında öğrenciden beklenenler aşağıdaki gibidir:

"Kelimelerin anlamlarını sorgulamak, bir durumun/olayın önemini sorgulamak, bir durumun/olayın farklı açılarını sorgulamak, bir durumun/olayın gerçek hayatla ilişkini sorgulamak, akran düşüncelerini sorgulamak, bir durumda/olayda bulunan kavramların benzerliklerini ve farklııklarını sorgulamak, iki veya daha fazla durumun/olayın benzerliklerini ve farklııklarını sorgulamak, bir durumun/olayın geçmişten bugüne olan değişimini sorgulamak, bir kişinin kişilik özelliklerine dair sorgulamalarda bulunmak, bir durumun/olayın kahramanlarının benzerliklerini ve farklııklarını sorgulamak, ucu açık sorulardaki bir durumu/olayı incelemek, tez ve antitez üretmek."

Sorgulama becerisinde, öğrencilerden genellikle metinle ilişkili bir durumun/olayın benzerliklerini ve farklılıklarını incelemesi; akran düşüncelerini ve akran ürünlerini irdelemesi beklenmektedir. Bu kategoride öğrencilerin sorgulaması gereken durumlarda/olaylarda belirli sınırlandırmalara gidilmiş ve sorgulamaların varacağı noktalar önceden geniş bir kapsamda belirlenmiştir. Yani ilgili temada öğrenciler yeni olgulara, kavramlara ve düşüncelere yöneltilmemiştir. 
Ancak öğrenciler; belirli olgu, kavram ve düşünceler kümesinde o kümeyi aşmayacak şekilde özgür ve aktif bırakılmıştır.

ilişki Kurma

Illişki kurma becerisi kategorisinde çalışma ve öğretmen kılavuz kitabında öğrenciden beklenenler aşağıdaki gibidir:

"Görsel-işitsel ilişki kurmak, kavram haritasıyla belirli bir kavram arasında ilişki kurmak, öğrenciler tarafından ortaya konulan kavramları birbiriyle ilişkilendirmek, bağlamdan hareketle kelime anlamını bulmak, kavramlar/düşünceler arasında karşılaştırma yoluyla ilişki kurmak, belirlenmiş değişkenleri bir kavramdan başka bir kavrama aktarmak."

Iliş̧i kurma becerisi birçok yerde analiz basamağı ile yakından ilişkilendirilmiştir. Bu durum "kavramlar/düşünceler arasında karşılaştırma yapma, bağlamdan hareketle kelime anlamını bulma" gibi öğrenciye yönelik beklentilerde kendini göstermektedir. İlişki kurma basamağında kavramların çokluğu göze çarpmaktadır. Sınıflama basamağındaki benzer bir durum bu basamakta da bulunmaktadır. Kavramlar arası ilişki kurmada iki farklı stratejiden yararlanılmıştır: birçok kavramı, belirli tek bir kavramla ilişkilendirmek; birçok kavramı belirsiz bir şekilde birbiriyle ilişkilendirmek. iliş̧ki kurma bu durum haricinde nadir de olsa temel seviyenin üstüne çıkmış, karmaşık bir hâl almıştır. Öğrencilerin okudukları masalları önceden bildikleri masallarla benzerlik ve farklılık açısından ilişkilendirmesi, geçmişteki insani temel ihtiyaçlar ve günümüzdeki insani temel ihtiyaçlar arasında karşılaştırma yoluyla bağlantı kurması bu duruma örnek olarak gösterilebilir.

\section{Tahmin Etme}

Tahmin etme becerisi kategorisinde çalışma ve öğretmen kılavuz kitabında öğrenciden beklenenler aşağıdaki gibidir:

"Kişilik özelliklerini tahmin etmek, görseller aracılığıyla metin içeriği tahmin etmek, bilinmeyen kelimelerin anlamını tahmin etmek, sorulan sorunun cevabını tahmin etmek."

Tahmin etme becerisi çoğunlukla; önceden kestirim yapma, sezgileri kullanma, olasılıkları düşünüp tartma olarak değil, değerlendirmeye yakın bir şekilde soru-cevaplarda kullanılmıştır. Öğrenciler "Ne olabilir?" şeklindeki soru kalıplarıyla tahmin etmeye yönlendirilmiştir. Bu yönlendirme bazen metnin kavranıp kavranmadığını sınamak ve metindeki odak noktalarını pekiştirmek için, bazen de metne ön hazırlık yapmak amacıyla kullanılmıştır. Ayrıca tahmin etme, ilişki kurma ve analiz basamağı ile beraber anlamı bilinmeyen kelimenin bağlam aracılığıyla anlamının ne olduğunun öğrenilmesine yönelik de kullanılmıştır. Fakat bu kullanım tahmin etmekten çok cümlenin birimlerini analiz edip bu birimler arasında ilişki kurmaya yöneliktir. Son olarak tahmin basamağında öğrencinin 
Türkçe Öğretiminde Etkinlik Stratejisi Geliştirmeye Yönelik Bir Durum Tespiti: 5. Sınıf Türkçe Çalışma ve Öğretmen Kılavuz Kitabı Örneği

bir konu/durumla ilgili kendi orijinal tahminini oluşturup o tahmine gerekçeler sunmasından çok öğrencilerin cevabın belli olduğu bir noktaya ulaşması hedeflenmiştir.

Analiz

Analiz becerisi kategorisinde çalışma ve öğretmen kılavuz kitabında öğrenciden beklenenler aşağıdaki gibidir:

"Kavramlar ve metinlerarası ilişki kurmak-karşılaştırmak, paragraf ve cümlelerden anlam çıkarmak, bağlam yoluyla anlamı bulmak, akranlarıyla cevapları arasındaki farklııkları bulmakkarşılaştırmak, metinden çıkarımda bulunmak, cevaba gerekçe sunmak, metinlerarası karşıllaştırma yapmak, tahminde bulunmak, anlam değişikliklerini fark etmek, metindeki soyut durumu açıklamak, araştırma yapmak, görsel yorumlamak"

Analiz becerisinde öğrencilerden en çok beklenen durumlar "metinden çıkarım yapmak, akranlarının cevaplarını karşılaştırmak/ilişki kurmak, zıt-benzer kavramları karşılaştırmak/ilişki kurmak ve kelimenin bağlam içindeki anlamını bulmak" şeklinde sıralanabilir.

Varsayımda bulunmak, sebep-sonuç ilişkisini bulmak, gruplamak, düzenlemek, gerekçelendirmek, araştırmak, yeniden organize etmek, ölçmek, geliştirmek vb. şeklindeki analiz basamağı durumlarına ilgili temada rastlanmamıştır. Analiz yapmaya yönelik etkinlikler çoğunlukla metinler etrafında şekillendirilmiştir.

Sentez

Sentez becerisi kategorisinde çalışma ve öğretmen kılavuz kitabında öğrenciden beklenenler aşă̆ıdaki gibidir:

"Ögeler arasında yeni bir desen kurmak, bir yargıуı/sonucu farklı cümlelerle tekrar yazmak, hayalinde canlandırmak, bir ürün geliştirmek, bir yargıyı/sonucu basitleştirmek, bir üründen hareketle yeni bir ürün ortaya çıkarmak, yazılı bir üründen hareketle ürünün şairi hakkında yorum yapmak, yazılı bir ürün ortaya koymadan önce taslak oluşturmak."

Sentez becerisine bakıldığında, bu basamağın yazma becerileri ile ilişkilendirildiği göze çarpmaktadır. Ortaya konulması istenen yazılı ürünler; cümle ve paragraf düzeyinde çeşitlenmektedir. Cümle düzeyinde istenen yazılı ürünler metinden ulaşılan sonuçları/yargıları farklı şekilde anlatma ve basitleştirme üzerinedir. Paragraf düzeyinde istenen yazılı ürünler için taslak oluşturma, yaratma becerisini kullanma, akran fikirlerinden faydalanma istenmiştir. Bu açıdan bakıldığında cümle düzeyinden paragraf düzeyine doğru basitten karmaşığa, kolaydan zora, metin merkezinden öğrenci merkezine kayan bir anlayış benimsenmiştir. Ayrıca öğrencilerden not defterlerindeki kelimelerden sözlük oluşturma çalışmasıyla sentez basamağııın düzenleme/derleme özelliğinden yararlanılmıştır. 


\section{Değerlendirme}

Değerlendirme becerisi kategorisinde çalışma ve öğretmen kılavuz kitabında öğrenciden beklenenler aşağıdaki gibidir:

"Daha iyi olan düşünceyi ya da ürünü seçmek, akranlarıla birlikte ortak bir sonuca ulaşmak, bir durumun/olayın değişkenlerini incelemek/değerlendirmek ve durum/olayla ilgili sonuca ulaşmak, akran düşüncelerini incelemek, bir durumun ögeleri arasında karşılaştırma yapmak, öz değerlendirme yapmak, bir kavram hakkında tartışmak, bir şairin kişilik özelliklerine yönelik yargılara varmak, metni değerlendirmek, ortaya konan yazılı ürünleri çeşitli açılardan değerlendirmek, bir durumu/olayı değerlendirirken fikrini açıķ̧a ifade etmek, tez/antitez sunarak görüşünü kanıtlamak, günlük hayatta karşılaşılan sorunları tecrübelerine göre değerlendirmek."

Değerlendirme basamağı "akran cevaplarını ve metni değerlendirme" gibi durumlarda az sayıda kullanılmıştır. Bunun yerine "sorgulama, eleştirme, analiz" basamaklarıyla beraber tartışma, değer biçme, hemfikir olma, kararlaştırma, aksini ispat etme, yorumlama, destekleme, puan verme, münazara yapma gibi çeşitli anahtar ifadeleri kapsayacak şekilde derinlemesine ele alınmıştır. Değerlendirme basamağı, yapısı gereği kendinden önceki basamakları da içermektedir. Fakat gerek öğretmen kılavuz kitabında gerekse çalışma kitabında bu basamak; sorgulama, eleştirme, analiz gibi basamaklarla oldukça açık yollarla girişik bir hale getirilmiştir. Bu sayede etkinliklerdeki değerlendirme sorularında ve öğretmen kılavuz kitabındaki değerlendirmeye yönelik yönergelerde "değerlendiriniz, ispat ediniz, sonuç çıkarınız, sebep sununuz" gibi kısıtlayıcı, sınırlı ve verimsiz değerlendirme yapılarından uzak kalınmıştır. Böylelikle değerlendirme basamağı; sorgulama, eleştirme ve analiz etme basamaklarını teker teker geçerek sistematik ve derin bir yapıya kavuşmuştur.

Temel Becerilere Yönelik Bulgular ve Yorumlar

Temel becerilere yönelik elde edilen veri aşağıdaki tabloda gösterilmiştir:

Tablo 2. Temel Becerilere Yönelik Sayısal Bulgular

\begin{tabular}{lcc}
\hline Temel Beceriler & Bulunduğu Etkinlik & $\%$ \\
\hline Türkçeyi Doğru Etkili ve Güzel Kullanma & 9 & 23 \\
\hline Eleştirel ve Yaratıcı Düşünme & 18 & 46 \\
\hline İletişim & 34 & 87 \\
\hline Problem Çözme & 4 & 10 \\
\hline Araştırma & 6 & 15 \\
\hline Bilgi Teknolojilerini Kullanma & 7 & 18 \\
\hline Girişimcilik & 4 & 10 \\
\hline Karar Verme & 3 & 8 \\
\hline
\end{tabular}


Türkçe Öğretiminde Etkinlik Stratejisi Geliştirmeye Yönelik Bir Durum Tespiti: 5. Sınıf Türkçe Çalışma ve Öğretmen Kılavuz Kitabı Örneği

1. temada bulunan 7 metindeki toplam 39 etkinlik içinde; Türkçeyi doğru, etkili ve güzel kullanma becerisi 9 (ortalama \%23), eleştirel ve yaratıcı düşünme becerisi 18 (ortalama \%46), iletişim becerisi 34 (ortalama \%87), problem çözme becerisi 4 (ortalama \%10); araştırma becerisi 6 (ortalama \%15), bilgi teknolojilerini kullanma becerisi 7 (ortalama \%18), girişimcilik becerisi 4 (ortalama \%10), karar verme becerisi 3 (ortalama \%8) etkinlikte kullanılmıştır.

Etkinliklerdeki kullanım sıklığı dağılımına göre "iletişim" becerisini; "eleştirel ve yaratıcı düşünme, Türkçeyi doğru, etkili ve güzel kullanma" becerileri takip etmektedir. "Bilgi teknolojilerini kullanma, araştırma, problem çözme, girişimcilik ve karar verme" ise en az kullanılan becerilerdir. Temel becerilere yönelik kategoriler ve bulgular aşağıda başlıklar hâlinde sunulmuştur.

\section{Türkçeyi Doğru, Etkili ve Güzel Kullanma}

Türkçeyi doğru, etkili ve güzel kullanma becerisi, temelinde tüm okuma, dinleme, yazma ve konuşma etkinlikleriyle gelişmeye uygun bir beceridir. Bu gelişim başka kazanımların ardında üstü örtülü bir şekilde gerçekleşebilir. Araştırmada bu beceriye yönelik öğretmen kılavuz kitabı yönergelerindeki ve çalışma kitabı etkinliklerindeki açık veri göz önüne alınmıştır.

Türkçeyi doğru, etkili ve güzel kullanma becerisi kategorisinde öğrenciden beklenenler aşağıdaki gibidir:

"Yazım ve noktalama kurallarına uymak, yabancı kelimelerin Türkçe karşılıklarını kullanmak, yabancı sözcüklere olumsuz puan vermek, işitilebilir bir ses tonuyla okumak, işitilebilir bir ses tonuyla konuşmak, vurgu ve tonlamaya dikkat etmek, göz teması kurmak, dinleyenleri ikna etmek, ortama uygun konuşmak, dramatize etmek"

Ulaşılan bulgulara göre bu basamakta Türkçe daha çok biçimsel kullanım açısından ele alınmıştır. Bu basamakta öğrencilerin yazma, konuşma ve okuma esnasında yazım ve noktalama kurallarına uyması ve sesletime dikkat etmesi üzerinde önemle durulmuştur. Türkçenin doğru, etkili ve güzel kullanımı açısından öğrencilerin konuşma esnasında göz teması kurmasına, dramatize etmesine, vurgu ve tonlamaya dikkat etmesine ve ikna etmek için ortama uygun konuşmaya dikkat etmesine yer verilmiştir. Fakat etkinliklerde öğrencilerin Türkçenin estetik unsurlarını keşfedip uygulamada bu estetik unsurları kullanmasına pek fırsat verilmemiştir.

\section{Eleştirel ve Yaratıcı Düşünme}

Eleştirel düşünme becerisinde öğrencilerin ulaşması gereken hedeflere, zihinsel beceriler basamağının sorgulama ve değerlendirme basamaklarında yer verildiği için bu alt başlık altında yaratıcı düşünmeye yönelik bulgular ele alınmıştır. Buna göre yaratıcı düşünme becerisinde öğrenciden beklenenler aşă̆ıdaki gibidir: 
"Bir konu ile ilgili farklı sorular üretmek, yeni bir ürün yaratmak ve bu ürünün özelliklerini belirlemek, kendilerine yardım edecek kişiler hayal etmek, yeni bir gezegen yaratmak, bir şehir kurmak, bir probleme yönelik çözüm üretmek, mektup yazmak."

Yaratıcı düşünme basamağında odaklanılan net bir nokta bulunmamaktadır. Fakat hedeflenen davranış ve ürünlere yönelik süreç bu basamakta ön plana çıkmaktadır. Bu basamakta öğrencilere yönelik yönergeler sadece "üretin, oluşturun, yazın" anahtar kelimeleriyle oluşturulmamıştır. Örneğin, gezegen yaratma etkinliğinde bölünmüş boş bir alana gezegen çizilecektir. Bu alanın yanındaki bölümde gezegenin adı, yaşı, kâşifi ve dünyaya uzaklığı gibi maddeler cevaplanacaktır. Bu parçaların birleşiminden ortaya bir ürün çıkacaktır. Problem çözme etkinliğinde, problem durumu kısaca tanımlanmış, A planı ve B planı kutucukları oluşturulmuş, planın nasıl uygulanması gerektiğine dair başka bir kutucuk verilmiş ve son olarak bu problemin tekrar yaşanmaması için neler yapılacağına dair bir bölüm verilerek plan oluşturmanın incelikleri ve plan oluşturma süreci öğrenciye sezdirilmiştir.

Yaratıcı düşünmenin yazma ve konuşma beceri alanlarında eşit bir dağılım gösterdiğini söylemek mümkündür. Bu beceri, konuşma etkinliklerinin hazırlık bölümünde fikir geliştirme amacıyla ve akran dayanışmasıyla fikir geliştirmede kullanılmıştır. Yazma etkinliklerinde ise çoğunlukla ilgili kutucuklara yazılan kısa cümlelerin oluşturacağı paragraf düzeyinde ürün ortaya koymak amacıyla kullanılmıştır.

\section{Problem Çözme}

Problem çözme becerisi kategorisinde çalışma ve öğretmen kılavuz kitabında öğrenciden beklenenler aşağıdaki gibidir:

\section{"Benzer sorunlara yönelik tedbirler almak, plan yapmak, çözüm önerisi üretmek."}

Problem çözme becerisi nicelik olarak en az olan basamaklardan birisidir. Bu basamakta öğrencilere okudukları metinlerle ilgili problem durumları verilmiş, bu problemlerin nasıl çözülebileceğine dair öğrencilerden alternatif çözümler istenmiştir. Problem çözmede kullanılan bu yöntemde kurgusal bir metin kullanılmıştır. Fakat başka bir etkinlikte problem çözme basamağı farklı şekilde ele alınmıştır. Öğrencilerin günlük hayatıyla ilişkili bir sorun olan tüketici sorunlarının ne olduğu öğrencilerden beklenmiştir. Öğrencinin ortaya koyduğu bu tüketici sorunlarının çözümünde yine öğrenciler birbiriyle etkileşim içinde yer almıştır.

\section{Araştırma}

Araştırma becerisi kategorisinde çalışma ve öğretmen kılavuz kitabında öğrenciden beklenenler aşağıdaki gibidir: 
Türkçe Öğretiminde Etkinlik Stratejisi Geliştirmeye Yönelik Bir Durum Tespiti: 5. Sınıf Türkçe Çalışma ve Öğretmen Kılavuz Kitabı Örneği

"Kelimenin anlamını sözlükten araştırmak, araştırma ödevi yapmak."

Araştırma basamağı "sözlük kullanma" ile özdeşleştirilmiştir. Öğrenci araştırma sürecinde kelime anlamını öğrenmek gibi pasif bir davranış sergilemektedir. Bunun haricinde başka bir etkinlikte öğretmen tarafından öğrencilere, araştırma yapılacak ürünler verilir ve araştırma kaynağı olabilecek İnternet adresi önerilir. Bu etkinlikte öğrenci; bilgiyi, teknoloji aracılı̆̆ıyla araştıran, bulan ve hedefe yönelik olarak kullanan aktif bir roldedir.

Bilgi ve Teknolojilerini Kullanma

Öğrenciler bilgi teknolojilerini aktif bir şekilde bireysel olarak kullanmamakta, sınıf içinde izleme ve dinleme aracılı̆ı̆yla bilgi teknolojilerinin pasif alıcısı olmaktadırlar. Sadece araştırma basamağında da belirtildiği gibi öğretmenin öğrencilerine araştırma yapmak için İnternet sitesi önermesi bunun istisnası olabilir.

Girişimcilik

Girişimcilik becerisi kategorisinde çalışma ve öğretmen kılavuz kitabında öğrenciden beklenenler aşağıdaki gibidir:

"Ticaretinin yapılabileceği bir ürün belirlemek, şehir kurmak, mektup gönderme vasıtasıyla girişimcilik becerilerini geliştirmek."

Girişimcilik becerisinde öğrencide ekonomik ve sosyal girişimcilik özelliklerinin gelişmesi hedeflenmektedir. Ticaretinin yapılabileceği bir ürünün belirlenmesi ticari girişimciliğe, bir problemi çözmek için yetkili biriyle temasa geçmek de sosyal girişimciliğe örnek olarak gösterilebilir. Girişimcilik becerilerini geliştirmek için oluşturulan etkinliklerde "eleştirel ve yaratıcı düşünme, değerlendirme, sentez, analiz, ilişki kurma, iletişim vs." zihinsel ve temel beceriler de bulunduğu için girişimcilik basamağı nicel olarak az olsa nitel olarak bu basamağın kuvvetli bir alt yapısının olduğunu söylemek mümkündür.

Karar Verme

Karar verme becerisi kategorisinde çalışma ve öğretmen kılavuz kitabında öğrenciden beklenenler aşağıdaki gibidir:

"En çok beğenileni belirlemek, grup olarak belirlemek, grup olarak kararlaştırmak, bir kişiyi sözcü olarak belirlemek."

"Karar verme" basamağı öğrencilerin bireysel öğrenme ve yapılandırma süreçlerinde kullanılmamıştır. Bu basamak, bir konu hakkında gruplar arasındaki daha iyi olma mücadelesinde ve grup içi ortak bir kavrama ya da yargıya ulaşma amacıyla etkinliklerde yer almıştır. Karar verme 
basamağının seçeneklerini çoğunlukla olaylar/durumlar ve kavramlar değil, kişiler oluşturmaktadır. Ayrıca bu basamakta "seçme" davranışını sergilerken öğrencilerin tabi olduğu birtakım ölçme ve değerlendirme kriterleri de bulunmaktadır. Bu yolla öğrencilere bu tip durumlarda karar vermenin belli birtakım kıstaslara bağlı olduğu, gelişigüzel yapılamayacağı gösterilmektedir.

Öğretmen Rolüne Yönelik Bulgular ve Yorum

Öğretmen rolüne yönelik elde edilen veri aşağıdaki tabloda gösterilmiştir:

Tablo 3. Öğretmen Rolüne Yönelik Sayısal Bulgular

\begin{tabular}{lcc}
\hline Öğretmen Rolü & Bulunduğu Etkinlik & $\%$ \\
\hline Iletişim & 34 & 87 \\
\hline Bilgiyi Bulmaya Yönlendirme & 28 & 72 \\
\hline Etkinliğe Yönlendirme & 18 & 46 \\
\hline Ön Bilgileri Harekete Geçirme & 11 & 28 \\
\hline Ölçme ve Değerlendirme & 10 & 26 \\
\hline Plan Yapma & 8 & 21 \\
\hline Ödüllendirme & 8 & 21 \\
\hline Dikkat Çekme & 6 & 15 \\
\hline Bilgiyi Sunma & 5 & 13 \\
\hline
\end{tabular}

1. temada bulunan 7 metindeki toplam 39 etkinlik içinde; iletişimsel rol 34 (ortalama \%87), bilgiyi bulmaya yönlendirme rolü 28 (Ortalama \%72), etkinliğe yönlendirme rolü 18 (ortalama \%46), ön bilgileri harekete geçirme rolü 11 (Ortalama \%28), ölçme ve değerlendirme rolü 10 (ortalama \%26), plan yapma rolü 8 (Ortalama \%21), ödüllendirme rolü 8 (ortalama \%21), dikkat çekme rolü 6 (ortalama \%15), bilgiyi sunma rolü 5 (ortalama \%13) etkinlikte kullanılmıştır. Iletişim kategorisi kullanım sıklı̆̆ı açısından "Temel Beceriler" kategorisinde incelenmiş olup “Öğretmen Rolü" kategorisinde sadece içerik olarak incelenecektir.

Etkinliklerdeki kullanım sıklığı dağılımına göre "bilgiyi bulmaya yönlendirme, etkinliğe yönlendirme" kategorisini "ön bilgileri hareket geçirme, ölçme ve değerlendirme, plan yapma, ödüllendirme" takip etmektedir. "Dikkat çekme, bilgiyi sunma" ise en az kullanılan kategorilerdir. Öğretmen rolüne yönelik kategoriler ve bulgular aşağıda başıklar hâlinde sunulmuştur.

\section{Bilgiyi Bulmaya Yönlendirme}

Bilgiyi bulmaya yönlendirme kategorisinde öğretmen rolüne yönelik anahtar ifadeler öğretmen kılavuz kitabında aşağıdaki başlıklar hâlinde sunulmuştur.

"Yönlendirmek, rehberlik yapmak, örnek cümle vermek, yardımcı olmak, öğrenciye yaptırmak, fark ettirmek, soru sormak, tartışma ortamı yaratmak, araştırma yaptırmak, teşvik etmek, kontrol ettirmek, fırsat tanımak, ipucu vermek, ulaşmayı sağlamak, dikkat ettirmek, karşılaştırma yaptırmak" 
Türkçe Öğretiminde Etkinlik Stratejisi Geliştirmeye Yönelik Bir Durum Tespiti: 5. Sınıf Türkçe Çalışma ve Öğretmen Kılavuz Kitabı Örneği

Yukarıdaki anahtar ifadeler detaylandırılmış ve örneklendirilmiş hâliyle aşağıda sunulmuştur:

"Öğrencilerin günlük hayatla ilgili bazı sorular sormasına ve bu soruların cevaplarını bulmasına rehberlik etmek; konuşmanın devam etmesi için yönlendirici sorular sormak; bilinmeyen kelimeler için örnek cümle vermek; metnin ana fikrini taşıyan cümleleri öğrencilere göstermek; kavramları karışık verip düzenlenmesini istemek; dil bilgisi kurallarını fark ettirmek; dil bilgisi kuralları ile ilgili tanımları öğrencilere oluşturtmak; alternatif cevaplara yönlendirmek; öğrencilerin cevaplarını sınıfa değerlendirtmek; kelimelerin anlamının bulunması için tartışma ortamı oluşturmak; ana fikir kavramının tanımını öğrencilere oluşturtmak; yardımcı fikirlerin bulunmasını sağlamak; öğrencilerin kelime anlamını bağlam ve kelime kökünden bulmasını teşvik etmek ve tahmin edilen anlamları sözlükten kontrol ettirmek; öğrencilere metnin oluş sırasını izlemeleri için ipucu vermek; öğrencilerin yaratıcılıklarını kullanmalarına fırsat tanımak, dersten önce araştırma ödevi vermek."

Elde edilen bulgulara göre bilgiyi bulmaya yönlendirme kategorisinde öğretmenden beklenen temel davranışlar metin ve etkinliklerle doğrudan ilgilidir. Bu noktada; örnek cümleler verip bilinmeyen kelimelerin anlamın buldurma, ana fikri ve yardımcı fikri buldurma, kavram sınıflandırma, dil bilgisi kurallarını fark ettirme, metinden çıkarımlar yaptırma göze çarpmaktadır. Metin ve etkinliklerle doğrudan alakalı olan bu davranışlar; düşünme, anlama, kavrama, analiz yapma zihinsel basamaklarıyla ilişkilendirilmiştir. Ancak bilgiyi buldurmada öğrencilerin sentez, değerlendirme ve yaratıcılık gibi üst düzey zihinsel basamakları kullanmasına fazla fırsat verilmemiştir.

Öğretmenin, metin ve etkinlikler ile doğrudan ilgili olmayan, günlük hayatla ilişkilendirilmiş yönlendirmeleri de bulunmaktadır. Bu bilgiyi buldurmaya yönelik davranışlar, çoğunlukla temaların hazırlık kısmıyla ilişkilendirilmiştir. Etkinlik sürecinde ve sonrasında odak noktası yine metinlere ve etkinliklere kaymaktadır.

Bilgiyi bulmaya yönlendirme kategorisinde, öğrencinin bilgiyi kendi zihninde yapılandırabilmesi için önem arz eden "araştırma" eylemine fazla yer verilmemiştir. Öğretmen, sadece sözlük kullandırarak ve dersten önce araştırma görevi vererek öğrencilerin araştırma yapmasına olanak vermektedir. Ayrıca araştırmanın nasıl yapılacağına ya da bilgi teknolojilerinin kullanımına yönelik yönergelere rastlanmamıştır.

Öğrencinin bilgiyi kendi zihninde yapılandırabilmesi için hem öğretmenle hem de akranlarıyla iletişim halinde olması da gereklidir. Bu açıdan bakıldığında öğretmen, bilgiyi buldurma aşamasında çoğunlukla öğrencilerle iletişim halindedir. Öğretmen, kendisinin öğrencilerle kurduğu iletişim kadar olmasa da öğrencilerinin birbiriyle iletişim haline geçmesine de olanak tanımaktadır. 
Öğretmen kılavuz kitabında, bilgiyi bulmaya yönlendirme çoğunlukla anahtar ifadelerin kullanımı ile sağlanmıştır. Bu yönlendirmenin ne şekilde olacağına dair sorumluluk öğretmene yüklenmiştir. Sadece bazı etkinliklerde, yönlendirme amaçlı sorulabilecek örnek sorulara yer verilmiştir.

Bilgiyi Sunma

Bilgiyi Sunma kategorisinde öğretmen rolüne yönelik anahtar ifadeler/ öğretmen kılavuz kitabında genel yönergeler bulunmamaktadır. Bu kategoriyle ilgili örnekler aşağıdaki gibidir:

"Etkinlikte kullanılacak kavramları metinden alıp öğrencilere vermek; metnin yazılış amacının ana fikir olduğunu öğrencilere anlatmak; yapılar ve yapıların maliyetleriyle ilgili oluşturulan bir listeye örnekler vermek; vergi konusunu anlamada güçlük çeken öğrencilere açıklamalar yapmak."

Örneklerden de anlaşılacağı gibi öğretmenin bilgiyi sunması, sonuca ulaştırmaktan öte öğrencilere yardımcı olmak amacıyla etkinliklerin hazırık sürecinde, etkinliklerin yapılma sürecinde ya da etkinliklerin sonuç kısmında eklemeler yapmasından ibarettir. Davranışçı öğrenme yaklaşımının bir özelliği olan bilgiyi sunma davranışı, nicel olarak az olmakla beraber, nitel açıdan yapılandırmacı öğrenme yaklaşımına entegre edilmiştir.

\section{Dikkat Çekme}

Dikkat çekme kategorisinde öğretmen rolüne yönelik anahtar ifadeler/öğretmen kılavuz kitabında genel yönergeler bulunmamaktadır. Bu kategoriyle ilgili örnekler aşağıdaki gibidir:

“ikilemelerin tekrar özelliğine sözel olarak dikkat çekmek; başka gezegenlerde yaşam olup olmadığının araştırıldığının bilgisini vermek; zevkli bir etkinlikle metnin konusunun bulanacağını söylemek; ilgili video izlenmeden önce devletin yapılar yapmak için nereden ve nasıl para bulduğunu öğrencilere sormak; günlük hayattan bir haber örneği paylaşmak; fabl türünü tanıtmak için sürahi, su ve çakıl taşından oluşan bir materyali sınıfa getirmek."

Dikkat çekme kategorisine ait bulgular incelendiğinde dikkat çekmenin üç farklı şekilde ortaya çıktığı görülmektedir: 1. Öğretmen kılavuz kitabında sadece sözel olarak dikkat çekme ifadesinin kullanılması. 2. Somut materyal aracılığıyla dikkat çekmek. 3. Etkinlik ya da konuyla ilgili örneklere yer vermek. Her ne kadar dikkat çekme üç farklı şekilde kullanılsa da bu maddelerin nicel olarak dağılımı azdır ve kendi içindeki kullanım şekilleri farklılaşmamıştır.

Dikkat çekme, sınıf ortamında yapısı itibariyle daha çok, derse hazırlık aşamasında öğrencinin derse odaklanmasını sağlamak amacıyla kullanılmaktadır. Fakat Ortaokul Öğretmen Kılavuz Kitabı 
Türkçe Öğretiminde Etkinlik Stratejisi Geliştirmeye Yönelik Bir Durum Tespiti: 5. Sınıf Türkçe Çalışma ve Öğretmen Kılavuz Kitabı Örneği

Türkçe 5. Sınıf'ta her etkinlik için bir hazırlık kısmı bulunmamaktadır. Bu durum dikkat çekme basamağının nicel ve nitel olarak öğretmen rolleri arasında kendine yer bulmasını zorlaştırmaktadır.

Etkinliğe Yönlendirme

Etkinliğe yönlendirme kategorisinde öğretmen rolüne yönelik anahtar ifadeler/ öğretmen kılavuz kitabında genel yönergeler bulunmamaktadır. Bu kategoriyle ilgili örnekler aşağıdaki gibidir:

"Öğrencilerin kendilerine yardımcı kişiler seçeceği bir etkinlik yapılmadan önce etkinlikte sorulan sorunun daha detaylı halini öğrencilere yöneltmek; masalların özelliklerinin belirleneceği bir etkinlik öncesi öğrencilere daha önce dinledikleri masalları hatırlamalarını istemek; ikileme çeşitlerinin bulunacağı bir etkinlik öncesi, bu ikileme türlerine yönelik karışık ve farklı ikilemeleri öğrencilere sunmak; bir etkinlikle ilgili videoları izlemeden önce seçici dinleme/izleme yöntemiyle izleyeceklerini ve etkinlikleri buna göre yapacaklarını açıklamak; yeni bir gezegenin kurulacağı bir etkinlikte öğrencilere yaratııılıklarını kullanmaları için yönlendirmeler ve hatırlatmalar yapmak; ekmeğin yapım aşaması ile ilgili bir etkinlik yapılmadan önce öğrencilere temel besin maddelerini sormak, bunlardan ekmeğin nasıl yapıldığını ve markete nasıl geldiği hakkında konuşacaklarını söylemek; bir yazma etkinliği sonunda oluş sırasıyla yazmanın önemli olduğunu belirtip sonraki yazma çalışmalarının bu şekilde daha nitelikli olacağını belirtmek; bir etkinlikte çalışma kitabında yer alan renklendirilmiş alanları kullanacaklarını öğrencilere hatırlatmak; bir ders öncesinden bir tartışma etkinliği yapacaklarına dair bilgilendirme yapmak; bir metin okunmadan önce öğrencilere oluşturdukları soruları akıllarında tutmalarını, çünkü cevapları metinde bulabileceklerini belirtmek."

Etkinliğe Yönlendirme basamağına ait bulgular incelendiğinde etkinliğe yönlendirmenin beş farklı şekilde ortaya çıktığı görülmektedir: 1. Etkinlikteki yönergeleri kısa bir süre önce aynen tekrarlamak; 2. Etkinlikteki yönergeleri daha detaylı şekilde öğrencilere açıklamak; 3. Etkinlik öncesinde etkinlikle ilgili çalışma yapmak; 4. Etkinlik sırasında, öğrencilerin odak noktasını kaçırmaması ve etkinliği daha kolay yapması için yardımcı yönergeler sunmak; 5 . Etkinlik sonrasında başka çalışmalar için benzer süreçlerin kullanılacağına dair bilgi vermek.

Ayrıca dikkat çekme ve ön bilgileri harekete geçirme, yer yer etkinliğe yönlendirme ile beraber kullanılmaktadır. Dikkat çekme aşamasında bir etkinliğin zevkli olacağı söylenmekte, bir başka etkinlikte de etkinlikle ilgili materyaller ve günlük hayattan örnekler sınıf ortamında gösterilmektedir. Ön bilgileri harekete geçirme aşamasında etkinlik öncesinde yapılan hatırlatmalarla yapılacak etkinlik arasında bağlantılar kurulmaktadır. 
iletişim

Iletişim kategorisinde elde edilen veri inceliğinde etkinlik öncesinde, etkinlik sırasında ve etkinlik sonrasında öğretmenin iletişimi başlattığı ve yönlendirdiği belirlenmiştir. Öğretmen kılavuz kitabında iletişim kurmaya yönelik bazı anahtar ifadeler aşağıdaki gibidir:

"Soru-cevap yöntemi kullanmak, grup değerlendirmesi yaptırmak, tartışma yaptırmak, öğrencilerin grup arkadaşlarıyla ortaya bir ürün koymasını istemek, öğrencilerin oluşturduğu ürünü tanıtmalarını/paylaşmalarını istemek, öğrenciyle birlikte bir karara varmak, öğrenciyle birlikte herhangi bir şeyi belirlemek, tüm sınıfın katılımıyla doğru cevaba ulaşmak, grup çalışması yaptırmak."

Yukarıda belirtilen anahtar davranışlar da göz önüne alındığında öğretmenin etkinliklerde üç farklı iletişim yönü kullandığı söylenebilir: 1. Öğretmenden öğrenciye doğru tek yönlü iletişim; 2. Öğretmenden öğrenciye ve öğrenciden öğretmene doğru çift yönlü iletişim. 3. Öğretmenden öğrenciye, öğrenciden öğretmene ve öğrenciden öğrenciye doğru üç yönlü iletişim. Etkinliklerde iletişim çoğunlukla üç yönlü kurulmuştur. Ardından çift yönlü iletişim gelmektedir. Tek yönlü iletişim ise oldukça az kullanıımıştır.

Tek yönlü iletişimde öğrenci iletiyi alan konumdadır ve pasiftir. Öğretmenin etkinlikle ilgili direktiflerini uygulamak dışında tepki vermemektedir. Öğretmenin direktifleri ise genellikle basittir ve etkinliğin nasıl yapılacağına yönelik sözel ifadelerden oluşmaktadır. Çift yönlü iletişimde öğrenci öğretmene dönütlerde bulunmaktadır. Bu dönütler; sorulan soruya cevap verme, fikrini açıklama aracılığıyla çoğunlukla düşünme, anlama, sınıflama, sıralama, ilişki kurma, analiz etme gibi zihinsel basamaklara yöneliktir. Üç yönlü iletişimde, öğrenci hem öğretmenleriyle hem de arkadaşlarıyla etkileşim hâlindedir. Üç yönlü iletişim; tartışma ortamına, grup değerlendirmesine, ürün oluşturulmasına ve oluşturulan ürünün paylaşılmasına olanak tanımaktadır. Bu sayede bu iletişim türüyle hem üst düzey zihinsel beceriler (sorgulama, eleştirme, analiz, sentez, değerlendirme) hem de temel beceriler (eleştirel ve yaratıcı düşünme, problem çözme, araştırma, girişimcilik ve karar verme) kullanılabilmektedir.

Üç yönlü iletişim aracılığıyla öğrencinin sadece bireyselliği değil, aynı zamanda topluluk içindeki sosyal yönü de ortaya çıkarılmıştır. Ayrıca yukarıda belirtilen zihinsel beceriler ve temel becerilerin yükü tek bir öğrencinin üzerine atılmamış, gruptaki akranlar arasında yapılandırılmış bir şekilde paylaştırımıştır. Bu etkileşim sayesinde her öğrenci aynı zamanda hem bir öğretici hem de bir öğrenen olmuştur. 
Türkçe Öğretiminde Etkinlik Stratejisi Geliştirmeye Yönelik Bir Durum Tespiti: 5. Sınıf Türkçe Çalışma ve Öğretmen Kılavuz Kitabı Örneği

\section{Ön Bilgileri Harekete Geçirme}

Ön Bilgileri Harekete Geçirme, öğretmen kılavuz kitabında "Hatırlatmak" eylemiyle özdeşleştirilmiştir. Öğretmen hatırlatma işini üç farklı şekilde yapmaktadır; 1. Yapılacak etkinliğin günlük hayatla ilişkisini göstermek, etkinlikteki kavramların günlük hayattaki karşılığını belirtmek ve günlük hayattan örnekler verip hatırlatma yapmak; 2 . Etkinlikte karşılaşılacak bilgiyle öğrencinin daha önceki derslerde karşılaştığını hatırlatmak; 3. Öğrencilerin karşılaşacağı dil bilgisi unsurlarına dair hatırlamalarda bulunmak.

Öğretmen bu alt başlıkta, etkinlik öncesinde etkinliklerdeki önemli unsurlara dair işlevsel bilgileri hatırlatmakta, geçmiş yaşantılarla bağlantı kurmakta, geçmiş ve günümüz arasında karşılaştırmalar yaptırmakta, yer yer metinlerarasıııktan faydalanmakta böylece öğrencilere anlamlı bir öğrenme fırsatı sunmaktadır.

\section{Ödüllendirme}

Ödüllendirme, öğretmen kılavuz kitabında "alkışlamak, ödüllendirmek, sınıf panosuna asmak" anahtar ifadeleriyle yer almaktadır. Ödüllendirme davranışı, hem grup olarak yapılan tartışmalarda/yarışmalarda hem de bireysel başarılarda kullanılmaktadır.

Öğretmenin uyguladığı/uygulayacağı bu ödüllendirme davranışı, davranışçı kuramdaki ödülceza sisteminden farklılık göstermektedir. Öncelikle öğretmen, herhangi bir şekilde öğrencilere yönelik bir cezalandırma davranışında bulunmamaktadır. Ödüller, öğrencilerin ulaşacağı bir nokta değil, ulaşması gereken noktaya varmasında teşvik edici ve cesaretlendirici bir araçtır.

\section{Plan Yapma}

Plan yapma; öğretmenin etkinlik öncesi, etkinlik sonrası ve etkinlik sırasında neler yapacağı ve bu süreci nasıl yöneteceği ile ilgilidir. Bu sebeple plan yapma diğer öğretmen rollerini kapsamaktadır. Plan yapma, yapısı itibariyle öğretmenin etkinlik süreci daha başlamadan etkinlik sürecinde neler yapılacağını adım adım belirlemesi/bilmesi anlamına gelmektedir. Fakat etkinliklere yönelik plan yapan öğretmen; otorite konumuna geçmemiş, öğrencileri sadece belirli direktiflere yönelik sınırlı dönütler veren pasif bireyler haline getirmemiştir. Buna göre plan yapma başlı̆ında öğretmenin sergilediği davranışlar aşağıdaki gibidir:

Etkinlik öncesinde öğretmen; etkinlik sırasında izlenecek basamakları öğrencilerle paylaşmakta, sınıf içi tartışma için grupları belirlemekte, etkinlik konusunun ne olduğunu ve hangi yönlerden ele alınacağını açıklamakta, değerlendirme ölçütlerini ortaya koymakta ve öğrencilere düşünmeleri için süre vermektedir. Etkinlik sırasında öğrencilerin etkinliğin kurallarına uyup 
uymadığını gözlemekte, kurallara uyulan noktalarda onları teşvik edip uyulmayan noktalarda onlara müdahale etmekte, sınıf düzeyinin uygunluğuna göre etkinlikleri tartışmaya dönüştürebilmektedir. Etkinlik sonrasında değerlendirmeye tabi tutulan etkinliklerden tüm katılımcıların oylarıyla en iyisinin seçilmesini sağlamakta ve alkış ya da sınıf panosunda sergi ile öğrencileri ödüllendirmektedir.

Plan yapma basamağına ayrıca ölçme ve değerlendirme sürecinde öğretmenin öğrencilerin yaşadığı öğrenme sorunlarının tespitinde ve bu sorunların çözümünde de rastlanmaktadır.

\section{Ölçme ve Değerlendirme}

Ölçme ve Değerlendirme, araştırmanın inceleme nesnesinin 1. Tema olması sebebiyle yoğunlukla öğrencilerin önceden edinmiş olduğu bilgi ve becerilerin düzeyinin ölçüldüğü "tanılayıcı değerlendirme" üzerine kurulmuştur. Tanılayıcı değerlendirmede öğretmen kılavuz kitabında da belirtildiği gibi îlkokul 4. Sınıf kazanımları referans alınarak öğrencilerin hazırbulunuşluğu tespit edilmiştir. Tanılayıcı değerlendirmede okuma, yazma ve konuşma becerileri değerlendirilmektedir. Bu değerlendirmeye konu edilen ölçme ve değerlendirme ifadeleri aşağıdaki gibidir:

"Okuma düzeyini tespit etmek için sesli okuma yaptırmak; sessiz okuma esnasında mırıldanma, dudakları kıpırdatma, parmakla satırı takip etme vb. davranışlarda bulunan öğrencileri tespit etmek; yazma düzeyini tespit etmek için öğrencilerin cümle ve paragraf düzeyinde oluşturduğu yazılı ürünleri dil, anlatım ve yazım bakımından belirlemek; öğrencilerin heyecan, ses, dil ve anlatım özelliklerini belirlemek."

Tanılayıcı değerlendirmeden sonra öğretmen, gözlem yoluyla öğrencilerin yaşadığı problemleri tespit edip tanılanan problemlere yönelik olarak sürece yayılan, çözüm niteliğinde planlamalar yapmak için biçimlendirici değerlendirme özelliği gösteren değerlendirmeler yapmaktadır. Fakat öğretmen kılavuz kitabında bu planlamalara yönelik detaylar paylaşılmamış, sürecin nasıl yönetileceğine dair bilgilendirmelerde bulunulmamıştır. Bu planlamalar genel geçer bir özellik göstermekte ve yönergelerde aşağıdaki şekilde geçmektedir:

"Öğrencilerin okuma sorunlarını gidermek ve okuma düzeylerini geliştirmek için çalışmalar planlamak; eğitim/öğretim sürecinde bu yanlışları düzeltmeye dönük planlamalar yapmak; konuşma gelişimleri açısından gerekli önlemleri alarak eğitim öğretim sürecini planlamak; öğrencilerin okuma hızını artırmak için gerekli önlemleri almak."

Öğretmen kılavuz kitabındaki 1 . temanın sonunda bulunan izleme özelliği gösteren değerlendirme sınavında, öğrencinin tema dâhilinde edinmesi gereken dil bilgisi, anlam ve bilgi odaklı sorular yer almaktadır. Bu sorular; yazılı yoklama, çoktan seçmeli, eşleştirme, doğru-yanlış, kısa cevap 
Türkçe Öğretiminde Etkinlik Stratejisi Geliştirmeye Yönelik Bir Durum Tespiti: 5. Sınıf Türkçe Çalışma ve Öğretmen Kılavuz Kitabı Örneği

şeklinde çeşitli tiplerde hazırlanmıştır. Fakat bu sorular, üst düzey zihinsel becerilere hitap etmeyip kavrama özelliği göstermektedir.

Ölçme ve Değerlendirme kategorisi, grup tartışmalarında ve akran değerlendirmelerinde de göze çarpmaktadır. Bu tartışma ve değerlendirmelerde ortaya konulacak sözlü ve yazılı ürüne yönelik değerlendirme kıstasları öğretmen tarafından verilmektedir. Fakat bu kıstaslar öğrencilere dayatılmamakta olup öneri niteliğindedir. Öğrencilerin kendileri başka kıstaslar da belirleyebilmektedir. Okuma, yazma, konuşmaya yönelik biçimsel kıstaslardan bazıları aşağıdaki gibidir:

"Uygun ve etkili bir ses tonuyla konuşmaya başlamak; işitilebilir bir ses tonuyla konuşmak; uygun yerlerde vurgu, tonlama ve duraklama yapmak; yabancı kelimelerin Türkçe karşılığını kullanmak; bağırmadan işitilebilir bir ses tonuyla okumak ve duyguyu iyi aktarmak; yazıyı giriş, gelişme ve sonuç bölümlerine ayırmak; düzgün ve okunaklı bitişik eğik yazı kullanmak; yazım ve noktalama kurallarına uymak."

Konuşma ve yazmaya yönelik içerik odaklı kıstaslardan bazıları aşağıdaki gibidir:

"Konuşmada gerçekçi unsurlara yer vermek; konuşmanın gerekçelerini yerine getirebilmek; ikna edici bir konuşma sergilemek; iddia üretebilmek; iddiayı gerekçelendirmek; karşı iddiayı çürütecek, geçersiz kılacak cümleler kurmak; yazma amacını belirlemek; yazının muhatabını doğru seçmek."

Ölçme ve değerlendirmeye yönelik olarak öğretmenin öğrencilere sunduğu kıstaslar incelediğinde, içerik odaklı ve biçimsel kıstasların eşit dağılım gösterdiğini söylemek mümkündür. Ayrıca öğretmen, az da olsa öğrencinin sosyal yönüne atıfta bulunan grup çalışmasına yatkınlık ve ortak iş yapabilmeye yönelik değerlendirmelerde de bulunmakta ve öğrencilere tüm çalışmalarının toplanacağı bir ürün dosyası oluşturtmaktadır.

\section{Tartışma ve Sonuç}

Zihinsel becerilerin etkinliklerde yer almasına yönelik nicel dağılım incelendiğinde, "analiz, sorgulama, değerlendirme, ilişki kurma, eleştirme ve sentez" basamaklarında \%50 civarında ya da \%50’nin üzerinde bir kullanım oranına rastlanmıştır. "Sıralama, sınıflama ve tahmin etme" becerileri etkinliklerde sınırlı düzeyde kullanılmıştır. Öğrencilerin bilişsel, duyuşsal ve sosyal gelişim düzeyleri dikkate alındığı zaman zihinsel becerilerin tamamını kullanabilme durumları somut işlemler döneminden ayrılma sürecinde olmaları sebebiyle farklı boyutlarla değerlendirilebilir. Ayrıca zihinsel becerilerin kendi içinde bir yönüyle sarmal, bir yönüyle hiyerarşik ve ardışık özellik göstermesi ve bu doğrultuda da zihinsel becerilerin kitapta orantısız bir dağılım sergilemesi etkinliklerin içeriği ve içerik 
doğrultusunda oluşturulan yönergelerle açıklanabilir. Etkinliklerde analiz basamağının çok fazla kullanılması, bu basamak dışında kalan "sorgulama, ilişki kurma ve eleştirme" gibi basamakların tamamlayıcısı olma durumuna bağııdır. Ancak analiz basamağının neredeyse etkinliklerin tamamında kullanılırken değerlendirme sürecinin bunun oldukça altında bir oranda kalması, ders kitabına yönelik bir eleştiri olarak sunulabilir. Çünkü analizin yapıldığı bir öğretim ortamında bunun gerekli duyuluyorsa sentez, duyulmuyorsa bile değerlendirme basamağı ile tamamlanması elzem niteliktedir. Bu eleştiriler yanında zihinsel becerileri oluşturan dokuz basamağın yarısından fazlasının yine etkinliklerin yarısından fazlasında kullanılması ders kitabında etkinlik stratejisi geliştirme açısından olumlu bir hazırlık, çalışma ve takibin yapıldığının göstergesi olarak açıklanabilir.

Zihinsel beceriler içerisinde analiz becerisinin "çıkarım yapma, ilişki kurma, araştırma ve organize etme" gibi anahtar ifadelerle gösterilmesi, bu basamağın etkinliklerde amaçlı olarak koordine edildiğinin göstergesi sayılabilir. Sorgulama becerisi açısından metin temelli "inceleme, irdeleme" gibi ifadelerle içeriğe yönelik olgu, kavram ve düşüncelere atıfta bulunulması da etkinlik stratejisi geliştirme açısından isabetli bir tutumdur. Ayrıca bu basamakta öğrencilerin sorgulama becerilerinin özgür ve aktif olarak kullanılmasına yönelik ortamlar hazırlanması da takdire değerdir. Sıralama becerisinin ise ilgili temada nicel açıdan az olmasının yanında yoğun nitelikte olmaması eleştiriye açık bir tutumdur. Bu beceri daha çok kurgusal yapıların dizilimine yönelik olan etkinliklerde yer almıştır. Ancak öğrencilerin bilgiyi aktif olarak oluştururken pasif olarak ayrıştırmasına yönelik bir sürecin sergilendiğini yani özelden genele ve genelden özele bir strateji oluşturulduğunu söylemek de mümkündür. Sınıflama basamağında farklı izlenceler oluşturulmuş, özellikle bazı kavramların belirli üst başlıklarda toplanması istenmiş ancak yapılandırmacı yaklaşımın temel gereklerinden olan sarmal özelliğe az yer verilmiştir. iliş̧ki kurma becerisi özellikle analiz basamağı ile ele alınmış, çoklu kavramlar tek bir kavramla ya da çoklu kavramlar kendi içinde ilişkilendirilmiştir. Tahmin etme becerisi etkinliklerde "kestirim, sezgisellik" kavramlarından ziyade doğrudan değerlendirmeye gidici bir nitelikle ele alınmıştır. Bu doğrultuda öğrencilerin tahmin etme becerilerini geliştirmede daha sınırlı öğretim ve benzer öğretim ortamları hazırlanmış ve etkinlik stratejileri açısından eleştiriye açık bir durum ortaya konmuştur. Sentez becerisi ise daha çok öğrencilerin yazma becerileri ile sınanmış ve örnek çalışmalar cümle ve paragraf düzeyinde çeşitlenmiştir. Sentez becerisinin diğer dil becerilerinde sınırlı bir şekilde kullanılması eleştiriye açık bir durum oluşturmuştur. Değerlendirme basamağı; sorgulama, eleştirme, analiz basamakları ile sık sık ilişkilendirilmiştir. Bu durum sağlam yapılı bir değerlendirme sürecine olanak tanımıştır. Ancak daha önce de söylendiği üzere analiz süreçlerinin birçoğu değerlendirmeye tabi tutulmamıştır.

Temel becerilere yönelik sekiz basamak değerlendirildiği zaman; iletişim becerisinin etkinliklerin neredeyse tamamında kullanıldığı, eleştirel ve yaratıcı düşünme becerisinden ise 
Türkçe Öğretiminde Etkinlik Stratejisi Geliştirmeye Yönelik Bir Durum Tespiti: 5. Sınıf Türkçe Çalışma ve Öğretmen Kılavuz Kitabı Örneği

etkinliklerin yarısında yararlanıldığı görülmüştür. Illetişimin, temel becerilerin özünü oluşturması bu sonucun göstergesidir. Öğrencilerin tüm gelişim düzeyleri doğrultusunda, etkinlik stratejileri açısından iletişim ve eleştirel/yaratıcı düşünme bağlantılı bir yapılandırma söz konusudur. Bu becerilerin ardından Türkçeyi doğru, güzel ve etkili kullanmanın öncül olduğu ve bunu bilgi teknolojilerini kullanma ve araştırmanın izlediği görülmektedir. Her ne kadar problem çözme, etkinliklerde en az kullanılan temel becerilerden de olsa sistematik bir derinliğe sahip olduğu ifade edilebilir. Aynı durum girişimcilik becerisi için de geçerlidir. Kullanım sıklığı açısından bu beceri az olmakla beraber, girişimcilik becerisinin kullanıldığı etkinlikler hem temel becerilerle hem de zihinsel becerilerle zenginleştirilmiştir. Karar verme becerisinin kullanım sıklığı en az olan beceri olması; karar vermenin bireysel çalışmalarda değil grup çalışmalarında kullanılmasıyla, grup çalışmalarında ise iyiyi belirleme, ortak bir noktaya ulaşma gibi kısıtlı alanlara sıkıştırılmasıyla açıklanabilir.

Türkçenin doğru, güzel ve etkili kullanımı açısından etkinlik stratejileri daha çok "göz teması kurma, vurgu ve noktalama" gibi biçimsel/dış yapısal temalarla oluşturulmuştur. Türkçenin estetik kullanımına ve yazılı ya da sözlü ürünlerin iç yapısına yönelik üretici eğitim ortamlarına yönelik etkinlikler çok sınırlı sayıdadır. Yaratıcı düşünme açısından "üretme, oluşturma, yazma" gibi yönergelerle benzer ve basit nitelikli etkinlikler oluşturulmamıştır. Yaratıcı düşünme; aşamalı fikir geliştirme ve grup çalışmasıyla fikir geliştirmeye yönelik, süreç gerektiren ve öğrencilerin ürettiği parçaların birleşiminden oluşmaktadır. Problem çözme, temel beceriler içerisinde çok az sayıda yer verilen bir basamak olmakla birlikte kurgusal bir metnin çevresinde ve gerçek hayatla ilişkili bir durumla yer yer yaratıcı düşünme ile beraber, analiz, ilişki kurma, sentez, değerlendirme gibi zihinsel becerilerin yardımıyla etkinliklerde yer almıştır. Araştırma becerisi ise yazılı materyaller üzerinde yapılacak çalışmalarla ilişkilendirilmiştir. Bu tür araştırma dışında öğrencilere araştırma ödevi de verilmiştir. Fakat araştırma türlerindeki çeşitliliğinin sınırlı, kullanılan materyallerin kısıtlı ve araştırma kapsamlarının dar olması sebebiyle öğrencinin araştırma becerisinin gelişebileceğini söylemek güçtür. Enformatik sürecin çok ileriye gittiği çağımızda bilgi teknolojilerini kullanmanın sadece İnternet sitesi önerileriyle sınırlanması, etkinlik stratejilerini eleştiriye açık bir hâle getirmektedir. Girişimcilik becerisi ise ticari ve sosyal boyutlarıyla etkinliklerde sunulmuş ve nitelik açısından "eleştirel ve yaratıcı düşünme, değerlendirme, sentez, analiz, ilişki kurma, iletişim" gibi zihinsel ve temel becerilerle ilişkilendirilerek yapılandırılmıştır. Karar verme becerisinde grup normu ve grup içinde danışıklı olarak ortaya çıkarılan bireysel tutumların kullanılmasıyla ve karar verme aşamasında dikkat edilecek ölçütlerin ortaya konulmasıyla isabetli bir yol izlenmiştir.

Zihinsel beceriler ve temel beceriler ekseninde etkinlik ve yönergelerdeki veriden elde edilerek kategorilendirilen öğretmen rolüne bakıldığında ise öğretmenin iletişim kuran ve bilgiyi bulmaya yönlendiren yönü oldukça ön plandadır. Yapılandırmacı yaklaşımın temelini oluşturan 
öğrenci merkezli eğitim ve bu doğrultuda öğretmenin en temel görevi olan rehberlik, etkinlik stratejilerinde de iletişim ve yönlendirme yönleriyle kendini göstermiştir. Öğretmen öğrencinin bilgiyi bulması, etkinliği anlaması ve bu doğrultuda ön bilgilerini harekete geçirip dikkat sergilemesi, plan yapması gibi basamaklarda yönlendirici noktadadır. Öğretmen rolüne yönelik bulguların yapılandırmacı yaklaşım doğrultusunda iyi düzeyde kurgulandığı ve etkinlik stratejisi oluşturmada kitabın başarı sağladığını söylemek mümkündür. Öğretmen, öğrencilerin ön bilgilerini harekete geçirmek için metinlerarasılıktan faydalanmaktadır. Davranışçı yaklaşımın temel özelliklerinden olan ödüllendirmeyi teşvik etme ve cesaret verme aracı olarak, bilgiyi sunmayı ise öğrenciye yardımcı olmak amacıyla bilgi eklemeleri şeklinde kullanmaktadır. Plan yapma sürecinde öğrencilere zaman zaman müdahale etmekte ve tartışma ortamı yaratmakta, öğrenciyi planlamaların pasif değil aktif bir unsuru hâline getirmektedir. Ölçme ve değerlendirme sürecinde özellikle öğretim süreci başlangııında tanılayıcı değerlendirmeyi kullanmakta, sadece tespit amacıyla değil çözüm üretme amacıyla da öğrencilerin durumunu ölçüp değerlendirmekte, grup değerlendirmelerine fırsat tanımaktadır. Tüm bu hususlar göz önüne alındığında etkinlik geliştirme stratejisi açısından kitapların becerilere göre farklı oranlarda da olsa yeterlik gösterdiği ve yapılandırıldığını söylemek mümkün olmaktadır.

\section{Kaynaklar}

Akgündüz, D., Aydeniz, M., Çakmakçı, G., Çavaş, B., Çorlu, M. S., Öner, T., ve Özdemir, S. (2015). STEM eğitimi Türkiye raporu: Günün modası mı yoksa gereksinim mi? İstanbul: Scala Basım.

Anagün, Ş. S., ve Yaşar, Ş. (2009). İlköğretim beşinci sınıf fen ve teknoloji dersinde bilimsel süreç becerilerinin geliştirilmesi. Ilköğretim Online, 8(3).

Bozkurt, Ö., ve Erdurur, K. (2013). Girişimci Kişilik Özelliklerinin Girişimcilik Eğilimindeki Etkisi: Potansiyel Girişimciler Üzerinde Bir Araştırma, Girişimcilik ve Kalkınma Dergisi, 8(2) :57-78.

Brooks, J. G., ve Brooks, M. G. (1999). In search of understanding: The case for constructivist classrooms. Alexandria, VA: Association for Supervision and Curriculum Development

Bukova-Güzel, E. ve Alkan, H. (2005). Yeniden yapılandırılan ilköğretim programı pilot uygulamasının değerlendirilmesi, Kuram ve Uygulamada Eğitim Bilimleri Dergisi, 5(2), s. 385-420

Chen, C. (2003). A constructivist approach to teaching: Implications in teaching computer networking. Information Technology, Learning, and Performance Journal, 21(2), 17.

Çiftçi, S., Sünbül, A. M., ve Köksal, O. (2013). Sınıf öğretmenlerinin yapılandırmacı yaklaşıma göre düzenlenmiş mevcut programa ilişkin yaklaşımlarının ve uygulamalarının değerlendirilmesi. Mersin Üniversitesi Eğitim Fakültesi Dergisi, 9(1).

Çubukçu, Z. (2010). Yapılandırmacı Yaklaşıma Göre Sınıf Yönetimi. Eğitime Bakış, Eğitim öğretim ve Bilim Araştırma Dergisi, 16, 37-40.

Demirel, Ö. (2008). Yapılandırmacı Eğitim. Eğitim ve Öğretimde Çağdaş Yaklaşımlar Sempozyumu, 03-04 Nisan, İstanbul: Harp Akademisi Basımevi.

Deryakulu, D. (2000). Yapıcı öğrenme. A. Şimşek (Ed. ), Sınıfta demokrasi. (s. 53-77). Ankara: Eğitim Sen Yayınları 
Türkçe Öğretiminde Etkinlik Stratejisi Geliştirmeye Yönelik Bir Durum Tespiti: 5. Sınıf Türkçe Çalışma ve Öğretmen Kılavuz Kitabı Örneği

Erdoğan, T. (2007). Illköğretim 3. sınıf Türkçe dersi öğretmen kılavuz kitabı ve öğrenci çalışma kitabının yapılandırmacı yaklaşıma uygunluğu. Mehmet Akif Ersoy Üniversitesi Eğitim Fakültesi Dergisi, 8(14), 163-172.

Gönen, S., ve Andaç, K. (2009). Gözden geçirme stratejisi ile desteklenmiş yapılandırmacı öğrenme yaklaşımının öğrencilerin basınç konusundaki erişilerine ve bilgilerinin kalıcılığına etkisi. Dicle Üniversitesi Ziya Gökalp Eğitim Fakültesi Dergisi, 12, 28-40.

Günay, R. (2015). Eğitim Fakültesinde Görev Yapan Öğretim Elemanlarının Yapılandırmacı Öğretmen Algıları. Elementary Education Online, 14(3), 845-861.

Güneş, F. (2011). Dil Öğretim Yaklaşımları ve Türkçe Öğretimindeki Uygulamalar/Language Teachıng Approaches And Theır Applıcatıons In Teachıng Turkısh. Mustafa Kemal Üniversitesi Sosyal Bilimler Enstitüsü Dergisi, 8(15).

Güneş, F. (2017). Türkçe öğretiminde etkinlik yaklaşımı. Ana Dili Eğitimi Dergisi, 5(1), 48-64

Hezen, E. (2009). Ilköğretim 1-5. Sınıflar Türkçe Dersi Öğretim Programı ve Kılavuzu'nun ögelerinin öğretim programında yer alan temel becerileri geliştirmeye uygunluğu. Yayımlanmamış Yüksek Lisans Tezi. Ankara: Hacettepe Üniversitesi Sosyal Bilimler Enstitüsü.

Kala, A. (2015). 2013 Kamu personeli seçme sınavı biyoloji alan bilgisi sorularının biyoloji öğretmenliği alan bilgisi yeterliklerine ve yenilenmiş Bloom taksonomisine göre analizi. Yayımlanmamış Yüksek Lisans Tezi. Marmara Üniversitesi Eğitim Bilimleri Enstitüsü, İstanbul.

Kan, A. Ü. (2006). Yeni Ilköğretim Programında Öngörülen Temel Becerileri Kazanmada Beşinci Sınıf Sosyal Bilgiler ve Türkçe Derslerinin Etkilerine ilişskin Öğrenci Görüşlerinin Değerlendirilmesi. (Diyarbakır ili Örneği). Yayımlanmamış Yüksek Lisans Tezi, Fırat Üniversitesi Sosyal Bilimler Enstitüsü, Elazığ.

Karadeniz, Y. (2010). "Türkiye'de girişimcilik eğitimi." Anahtar Dergisi, Temmuz, 42-44.

Karaman, i. (2005). Erzurum ilinde bulunan liselerdeki fizik sınav sorularının Bloom taksonomisinin basamaklarına göre analizi. Gazi Üniversitesi Gazi Eğitim Fakültesi Dergisi, 25(1).

Koç, G. (2010). Yapılandırmacı sınıflarda öğretmen-öğrenen rolleri ve etkileşim sistemi. Eğitim ve Bilim, 32(142).

Koray, Ö., Altunçekiç, A., ve Yaman, S. (2005). Fen bilgisi Öğretmen Adaylarının Soru Sorma Becerilerinin Bloom Taksonomisine Göre Değerlendirilmesi. Pamukkale Üniversitesi Eğitim Fakültesi Dergisi, 17(17), 33-39.

Kurudayıŏlu, M., ve Çetin, Ö. (2015). Temel Beceriler ve Türkçe Öğretimi. Ana Dili Eğitimi Dergisi, 3 (3), 1-19.

Millî Eğitim Bakanlığı (MEB). (2005). Ilköğretim 1-5 sınıf programları tanıtım el kitabı. Ankara: Devlet Kitapları Müdürlüğü Basımevi.

Millî Eğitim Bakanlığı (MEB). (2009). Ilköğretim Türkçe dersi öğretim programı ve kılavuzu (1-5. Sınıflar). Ankara: Devlet Kitapları Müdürlüğü Basım Evi.

Millî Eğitim Bakanlığı (MEB). (2015). Türkçe Dersi (1-8. Sınıflar) Öğretim Programı. Ankara: Ankara: Millî Eğitim.

Millî Eğitim Bakanlığı (MEB). (2017). İlköğretim Türkçe dersi öğretim programı (ilkokul ve ortaokul 1, 2, 3, 4, 5, 6, 7 ve 8. Sınıflar). Ankara: Millî Eğitim.

Ocak, G. ve Tavlı, M. (2010). Yapılandırmacı öğrenme ortamları. Eğitime Bakış, Eğitim öğretim ve Bilim Araştırma Dergisi, 16, 56-60.

Özatalay, H. (2007). Ilköğretim I. Kademe Türkçe Öğretim Programında Öğrencilere Kazandırılması Hedeflenen Temel Becerilerin Ders Kitaplarında Kullanılmasına Iliş̧kin Durum Çalışması. Yayımlanmamış Doktora Tezi, İstanbul: Marmara Üniversitesi.

Özdemir, S. M. (2005). Üniversite Öğrencilerinin Eleştirel Düşünme Becerilerinin Çeşitli Değişkenler Açısından Değerlendirilmesi. Türk Eğitim Bilimleri Dergisi, 3(3), 297-316.

Özerbaş, M. A. (2007). Yapılandırmacı Öğrenme Ortamının Öğrencilerin Akademik Başarılarına ve Kalıcılığına Etkisi. Türk Eğitim Bilimleri Dergisi, 5(4), 609-635. 
Özmantar, M. F., ve Bingölbali, E. (2009). Etkinlik tasarımı ve temel tasarım prensipleri. İlköğretimde Karşılaşılan Matematiksel Zorluklar ve Çözüm Önerileri. Pegem Akademi, Ankara.

Schunk, D. H. (2009). Öğrenme Teorileri-Eğitimsel Bir Bakışla (Çev. : Muzaffer Şahin). Ankara: Nobel Yayın.

Tarnopolsky, O. B. (2017). Developing a constructivist textbook of English for university students majoring in tourism. Austrian Journal of Humanities and Social Sciences, (1), 56-62.

Türnüklü, A., ve Bekmezci, E. (2010). Sosyal yapılandırmacılığın penceresinden öğrencilerin davranışlarının yönetimi. Eğitime Bakış Dergisi, 16, 27-31.

Willis, J. (1996). A flexible framework for task-based learning. Challenge and change in language teaching, 5262.

Yahşi Cevher, Ö. (2008). Türkçe programının ilköğretim 6. sınıf düzeyinde eleştirel düşünme becerisine etkililiği. Yayımlanmamış Yüksek Lisans Tezi. Sakarya Üniversitesi Sosyal Bilimler Enstitüsü.

Yaşar, Ş. (1998). Yapısalcı kuram ve öğrenme-öğretme süreci. Anadolu Üniversitesi Eğitim Fakültesi Dergisi, 8(12), 68-75.

Yıldırım, A., ve Şimşek, H. (2013). Sosyal bilimlerde nitel araştırma yöntemleri. Seçkin Yayıncılık.

Yurdakul, B. (2005). Eğitimde Yeni Yönelimler, (Ed. Özcan Demirel) PegemA Yayıncılık. Ankara, 39-65. 